\title{
Sex and neo-sex chromosomes in Orthoptera: a review*
}

\author{
Author(s): Elio Rodrigo Castillo, Dardo Andrea Marti, Claudio Juan Bidau
}

Source: Journal of Orthoptera Research, 19(2):213-231. 2010.

Published By: Orthopterists' Society

URL: http://www.bioone.org/doi/full/10.1665/034.019.0207

BioOne (www.bioone.org) is an electronic aggregator of bioscience research content, and the online home to over 160 journals and books published by not-for-profit societies, associations, museums, institutions, and presses.

Your use of this PDF, the BioOne Web site, and all posted and associated content indicates your acceptance of BioOne's Terms of Use, available at www.bioone.org/page/terms_of_use.

Usage of BioOne content is strictly limited to personal, educational, and non-commercial use. Commercial inquiries or rights and permissions requests should be directed to the individual publisher as copyright holder. 


\title{
Sex and neo-sex chromosomes in Orthoptera: a review*
}

Submitted September 8, 2010, accepted October 22, 2010

\author{
Elo Rodrigo Castillo, Dardo Andrea Marti, Claudio Juan Bidau
}

(ERC, DAM) Laboratorio de Genética Evolutiva. Universidad Nacional de Misiones. Félix de Azara 1552. 3300. Posadas, Misiones Argentina. (CJB)Paraná y Los Claveles, Garupá, 3304, Misiones, Argentina. Email: bidau50@gmail.com (correspondence) (DAM)Consejo Nacional de Investigaciones Científicas y Técnicas (CONICET).

*Dedicated with love to María Victoria (Vito), Rodrigo (Ró) and Juan Bautista (Tateto), our youngest sons.

'I trust that the element here discussed will attract the attention which I am convinced it deserves, and can only hope that my investigations will aid in bringing it to the notice of a larger circle of investigators than that now acquainted with it.'

Clarence E. McClung, 1901

'The small chromosome itself may not be a sex determinant, but the conditions in Tenebrio indicate that sex may in some cases be determined by a difference in the amount or quality of chromatin in different spermatozoa. This is much the more suggestive part of the work...'

Nettie Maria Stevens, 1905

"The evolution of the sex-determining mechanism is one of the most interesting chapters of chromosomal evolution, but the phylogenetic history of the sex chromosomes can only be interpreted when the mechanism of meiosis is understood.'

Michael J. D. White, 1941

'The realisation that surveys of sex chromosome hybrid zones can answer questions relating to the early evolution of sex chromosomes is exciting because such hybrid zones are already known and waiting to be analyzed.'

Paris Veltsos et al. 2008

\begin{abstract}
We review historical and pioneering work as well as recently published papers about orthopteran sex chromosomes and neo-sex mechanisms, highlighting Michael White's significant contributions. Meiotic research in Orthoptera in the early twentieth century was central to confirming that sex determination had a chromosomal basis: the study of sex chromosomes produced fundamental support to the chromosome theory of heredity. We also explore recent theoretical models of sex-chromosome evolution and consider the possible causes of crossing over restriction in proto-sex chromosomes, as well as the progressive differentiation (erosion and degeneration) of the $\mathrm{Y}$ chromosome in neo-chromosome systems in different taxa. We discuss neo-XY and neo- $\mathrm{X}_{1} \mathrm{X}_{2} \mathrm{Y}$ chromosome systems of South American Melanoplinae (Acrididae) as potential experimental models to study steps in sex-chromosome evolution because these systems fall within a continuum of evolutionary stages, some of them recently established. We also provide an explanation for the disproportionate frequency of neo-sex systems and Robertsonian-derived karyotypes in Neotropical Melanoplinae, based on the centromeric drive theory, and propose that Neotropical melanoplines' high karyotypic diversity supports an ancient South American origin of the subfamily. We discuss the hypothesis that neo-sex chromosome systems produce favorable new linkage relationships between genes in the $\mathrm{X}$ and the involved autosome, some of which could be sex determination related,
\end{abstract}

creating a new balance between sex chromosomes and autosomes. We also review Mesa's hypothesis that, based on the observed fact that no major taxon of orthopterans shows neo-sex chromosomal mechanisms in all their species, the acquisition of a neo-sex chromosome system could condemn species of grasshoppers to a short evolutionary career. Little is yet known about the role of neo-Y chromosomes in Orthoptera, thus mostly speculative explanations about neo-sex chromosome function can be made at present. New studies with modern molecular techniques are needed to understand chromosomal sex determination in Orthoptera, which could in turn help explain the role of new chromosomal sex systems in grasshopper species.

\section{Key words}

grasshopper, recombination, sex chromosomes, sex determination, structural rearrangements

\section{Discovery of sex chromosomes within the framework of the chromosome theory of heredity}

Sex chromosomes and the genetics of sex determination have been the subject of study by cytologists and geneticists for more than 120 years (Morgan 1903; Morgan et al. 1915; Goldschmidt 1923; Wilson 1925; Darlington 1958; Ohno 1967, White 1973, Charlesworth 1991, 2002, 2004; Ferguson-Smith 2007; Kingsland 2007; Kaiser \& Bachtrog 2010). The early interest in the mechanisms and physiology of sex determination was fueled by the 'rediscovery' of Mendel's principles in 1900. As early as 1907, the American Society of Naturalists organized a symposium on sex determination, where papers by leading cytologists and experimental breeders reviewed the most relevant information to date, as well as the fundamental problems that Mendelism and increasing cytogenetic information posed (Blackeslee 1907, Harper 1907, Lillie 1907, Morgan 1907, Wilson 1907).

As Smih (1907) wrote in his review on sex determination, 'we actually see that the sexual characters do segregate into two sharply separated sets of individuals, the males and the females, as if maleness and femaleness were in some way allelomorphic to one another, while the occurrence of hermaphrodite forms and the latent presence in one sex of characters proper to the opposite sex indicate the phenomenon of heterozygotism or sex hybridism'. This is clearly early Mendelian thinking, and in fact the first Mendelian theories of sex were formulated by Bateson and Saunders (1902), and Castle (1903).

For example, Castle (1903) wrote: 'It is an attempt [his theory] to correlate three ideas,...: (1) The idea of Darwin ('76), that in animals and plants of either sex the characters of the opposite sex are latent'; (2) the idea of Mendel ('66), that in the formation of the gametes of hybrids a segregation of the parental characters takes place, and when in fertilization different segregated characters meet, one will dominate, the other become latent or recessive; (3) the idea of Weismann ('93) that 
in the maturation of egg and spermatozoon a segregation of ancestral characters takes place, and that this segregation is attended by a visible reduction in the number of chromosomes in the germinal nuclei'.

However, although chromosome behavior is central to Castle's theory, both in bisexual and parthenogenetic species, no mention of possible sex chromosomes is made, although there was growing evidence of their existence (McClung 1899, 1901, 1902). Also, Bateson and Saunders (1902) had considered that since all hereditary characteristics of the offspring are determined by the gametes, and since sex should be included among those characteristics, if all the gametes of each parent were of a single type, there would be only one class of zygotes. Thus, the production of individuals of both sexes would be impossible.

The connection between chromosomes and sex determination followed the discovery by Hermann Henking (1858-1942) in 1891 that in Pyrrhocoris apterus, a heteropteran, females showed 12 pairs of homologous chromosomes that formed 12 bivalents during meiosis, while males showed only 11 bivalents, plus a lone element (vaguely called 'nucleolus' or 'chromatic element') which later came to be known as the "accessory chromosome" (incidentally, in one of his figures, Henking labelled the accessory chromosome as " $\mathrm{X}$ " which led ultimately to the denomination of "X chromosome").

Henking (1891) did not grasp the full significance of his discovery. This was done by Clarence Erwin McClung (1870-1946), an outstanding grasshopper cytologist working initially at the University of Kansas, Lawrence, after the 'rediscovery' of Mendel's Laws in 1900. Through McClung, orthopterans fully enter this scenario (Ault 1996, Kingsland 2007).

McClung (1899) described the meiotic behavior of what was for the first time called, 'accessory chromosome', in male Xiphidium fasciatum (Conocephalus fasciatus), a tettigoniid. He later confirmed his observations in Hippiscus sp., an acridid grasshopper (McClung 1901). He correctly interpreted this element as chromatin, [not an ambiguous 'chromatin nucleolus' or 'degenerating chromatin' as Thomas Harrison Montgomery (1873-1912) had done for 'Pentatoma' (Euschistus variolarius) (Montgomery 1898, 1901), and not a nucleolus, as Wilcox (1895) had done for an analogous structure in Caloptenus femur rubrum (Melanoplus femurrubrum)]. McClung equated it to the findings of Henking's (1891) ' $\mathrm{X}$ ' element [incidentally, McClung (1899) also labelled the 'accessory chromosome as ' $\left.\mathrm{X}^{\prime}\right]$.

Although Montgomery prosecuted his cytological work on spermatogenesis of many animal species (Montgomery 1901, Conklin 1913), he did not realize the importance of his observation until the work of McClung, Nettie Maria Stevens (1861-1912) and Edmund Beecher Wilson (1856-1939). However, Montgomery (1910), remained skeptical about McClung's original hypothesis that sex determination had a chromosomal basis.

McClung also described changes in what we now call differential pycnosis or allocycly of the accessory element with respect to the rest of the chromatin, an observation pioneered by Montgomery (1898) in Heteroptera. However, Montgomery did not readily relate this X-body to sex dimorphism, since he did not study females.

Soon, however, the real nature of the problem was understood by McClung. In 1901, he published a short note in advance of a larger paper that appeared in 1902. By this time Mendel's principles were the latest scientific sensation, and Walter Stanborough Sutton (1877-1916), one of McClung's students, had produced outstanding work on the meiotic chromosomes of Brachystola magna, the basis of the Chromosome or Sutton-Boveri Theory of Heredity (Sutton 1901, 1902, 1903; Crow \& Crow 2002; Bidau \& Martí 2010). McClung (1901) wrote: 'Upon the assumption that there is a qualitative difference between the various chromosomes of the nucleus, it would necessarily follow that there are formed two kinds of spermatozoa which, by fertilization of the egg, would produce individuals qualitatively different. Since the number of each of these varieties of spermatozoa is the same, it would happen that there would be an approximately equal number of these two kinds of offspring.'

In his 'large' paper, McClung (1902) is more emphatic: 'A most significant fact, $[. .$.$] , is that the element is apportioned to but one half of$ the spermatozoa. Assuming it to be true that the chromatin is the important part of the cell in the matter of heredity, then it follows that we have two kinds of spermatozoa that differ [...] in a vital matter. We expect, [...] in the offspring two sorts of individuals in approximately equal numbers, [...], that exhibit marked differences in structure. A careful consideration will suggest that nothing but sexual characters thus divides the members of a species into two well-defined groups, and we are logically forced to the conclusion that the peculiar chromosome has some bearing upon this arrangement.' (McClung 1902).

This hypothesis was initially resisted by some (Morgan 1903, 1907; Montgomery 1910; see below) but further work by Sutton (1902, 1903) in Brachystola magna, Baumgartner (1904) in Gryllus, and particularly, Nettie Stevens (1905), strongly supported McClung's views and improvements upon his original interpretation were made by E.B. Wilson (1905a,b,c, 1909; Martins 1999).

Although Sutton produced two epoch-making papers on the relation of chromosomes with Mendelian principles (Sutton 1902, 1903; Crow \& Crow 1902; Bidau \& Martí 2010), and correctly interpreted that male B. magna had 23 chromosomes, the unpaired element being the 'accessory chromosome', he was wrong in reporting 22 chromosomes in the female. This is not surprising, considering the methods used at that time, and the fact that even today, oogenesis is a difficult process to study in animals. But this erroneous observation led McClung (1902), when proposing his novel hypothesis of chromosomal sex determination, to assume that the 'accessory chromosome' was only present in males thus, male determining. In fact, as later demonstrated for most Acridids, males have indeed 23 chromosomes (with one X), while females, including B. magna, 24. McClung (1902) wrongly considered that the 'element' produced the development of males when present, and of females, when absent.

Another much-discussed issue was the idea of McClung's that sex determination should be qualitative; that is, sex chromosomes were really sex determinants (McClung 1901, 1902). Authors such as Wilson (1905c), who firmly believed in sex chromosomes and helped resolve some of the uncertainties of McClung's hypothesis-i.e., 'The foregoing facts irresistibly lead to the conclusion that a causal connection of some kind exists between the chromosomes and the determination of sex; and at first thought they naturally suggest the conclusion that the idiochromosomes and heterotropic chromosomes are actually sex determinants, as was conjectured by McClung in [the] case of the 'accessory' chromosome.' - opposed this idea: 'Analysis will show, however, that great, if not insuperable, difficulties are encountered by any form of the assumption that these chromosomes are specifically male or female sex determinants. It is more probable, for reasons that will be set forth hereafter, that the difference between eggs and spermatozoa is primarily due to differences of degree or intensity, rather than of kind, in the activity of the chromosome groups in the two sexes; and we may here find a clue to a general theory of sex determination...' (see Kingsland 2007).

The prominent geneticist Thomas Hunt Morgan (1866-1945), who in this early period considered that both Mendelian and Darwinian theories lacked in plausibility and was the first to distinguish between qualitative and quantitative theories of sex determination, was also inclined to the latter view and considered that no single chromosome could carry specific hereditary traits 
including sex (a view that he changed the next decade through his own work in Drosophila). By a quantitative interpretation he meant (Morgan 1909): '...that male and female are two alternate possibilities of the living material, which possibility is realized depending on quantitative factors [...] The gametes are not, therefore, male and female, but contain certain factors which, when combined, give rise, in an epigenetic fashion, to one or the other alternative'.

In the phylloxerans (aphids) studied by him the'... loss of certain chromosomes from the male egg appears to follow, not to precede the size relation. [. . .]. But there is nothing in these facts that shows that the effects are directly quantitative rather than that observable quantitative differences accompany, or follow in some cases, more profound changes'. Furthermore: '...although the hypothesis is ostensibly based on the presence of certain chromosomes which are assumed to be male and female determining respectively, yet to these chromosomes, which are to all appearances identical, are ascribed exactly opposite functions'. It was also believed that the amount of chromatin (and its relation to cytoplasm) produced by the presence or absence of the accessory chromosome, would determine maleness or femaleness [see also Jordan (1910)].

Other points of confusion were: the existence of thelytokous parthenogenesis in many species and arrhenotoky in the Hymenoptera, the different interpretations of the real nature of the accessory chromosomes, as shown by the many names they received (chromatin nucleoli, degenerating chromatin, idiochromosomes, heterochromosomes, heterotropic chromosomes) and the extreme diversity of the meiotic systems that were being studied, as Stevens (1905) stated in the concluding paragraph of her famous paper (see below): 'There appears to be so little uniformity as to the presence of the heterochromosomes, even in insects, and in their behaviour when present, that further discussion of their probable function must be deferred until the spermatogenesis of many more forms has been carefully worked out'.

Despite the controversies, in the second decade of the twentieth century the existence of sex chromosomes was firmly established thanks to McClung's first suggestion. The fine work of Nettie Maria Stevens (1861-1912), a biologist working at Bryn Mawr College, was central to the recognition of sex chromosomes as a fundamental component of the genetic system of most animal species. Her essential 'Studies in spermatogenesis' paper (Stevens 1905) in which she analyzed chromosomes of Termopsis angusticollis (termite), Stenopelmatus sp. (sand cricket), Blatella germanica (cockroach) and Tenebrio molitor (beetle), among other invertebrates, provided the first evidence that sex-chromosome sexual dimorphism may be not only numerical, but also morphological. She discovered that in T. molitor, although males and females share the same diploid number $(2 n=20)$, males have a heteromorphic pair of chromosomes [one large, now called ' $\mathrm{X}$ ', and one small, the ' $\mathrm{Y}^{\prime}$, a term coined by Wilson (1909)]. Stevens (1905) had labeled this chromosome, 's' (probably because of its small size). However, in females the small chromosome is absent and replaced by a second $\mathrm{X}$.

In spermatogenesis, both heteromorphic chromosomes pair (in what was later called a 'parachute' fashion) and segregate regularly thus: 'The egg nuclei of the female must be alike so far as number and size of chromosomes are concerned, while it is absolutely certain that the spermatids are of two equal classes as to chromatin content of the nucleus'. Furthermore: '...it seems certain that an egg fertilized by a spermatozoön which contains the small chromosome must produce a male, while one fertilized by a spermatozoön containing 10 chromosomes of equal size must produce a female. The small chromosome itself may not be a sex determinant, but the conditions in Tenebrio indicate that sex may in some cases be determined by a difference in the amount or quality of the chromatin in different spermatozoa.'
Stevens firmly believed in a Mendelian model of sex determination through sex chromosomes and extended her observations to many other insect species (Stevens 1906). Indeed, in a subsequent paper Stevens (1908) identified the sex chromosomes (X and Y) of Drosophila melanogaster (then called D. ampelophila), the insect that would soon become, through Morgan's group, the basis of one of the most fruitful genetical research programs in the history of genetics. What is more relevant, Stevens not only performed very detailed and innovative cytological work, she complemented it with experimental work that reinforced her conclusions (Delgado Echeverría 2000, Shwartz 2008).

Further work by McClung, Wilson and others demonstrated the widespread occurrence of sex chromosomes in many groups of animals and plants, the incredible variation in their number and morphology, and the possibility of complex evolutionary structural rearrangements affecting sex chromosomes, where grasshoppers played a fundamental role (see below).

The exact mode in which sex chromosomes are involved in sex determination had to wait many years to begin to be fully understood. However, a very important advance in the acceptance of sex chromosomes as essential components of the genetic systems, benefited enormously from the work of a former critic of both Mendelism, the Chromosome Theory and sex chromosomes as sex determinants: Thomas Hunt Morgan. Indeed, Morgan's group finally demonstrated the existence of sex-linked and autosomal-linked genes in Drosophila, and the connection between Mendelian factors and chromosomal behavior during meiosis (Morgan et al. 1915) leading to a true synthesis between Mendelism and the Chromosome Theory (Kingsland 2007).

\section{Sex chromosome evolution}

The next years saw an explosion of cytogenetic studies using grasshoppers as an experimental model. These investigations ceased to be only descriptive and began to gradually assume an important role in evolutionary and genetic studies (Bidau \& Martí 2010). Eventually, it was Michael White who placed orthopteran chromosomes in a relevant position in evolutionary studies and marked the beginning of a new wave of knowledge from the evolutionary point of view. Although White's interests covered many aspects of chromosome biology, he made relevant contributions to sex chromosome mechanisms and the evolution of sex chromosomes (White 1940a, b; 1941a,b).

Already in 'Animal Cytology and Evolution' (White 1945), the first compendium of cytogenetic information in the animal kingdom that introduced chromosomes within the modern synthesis, White discussed the, now widely accepted, hypothesis that heteromorphic sex chromosomes have evolved from a pair of morphologically identical autosomes, that these had restricted mutual recombination and gradually, both elements diverged morphologically and genetically from each other (Darlington 1958, Ohno 1967, White 1973, Charlesworth et al. 2005, Moore 2009).

Originally, White interpreted the problems of sex-chromosome evolution (mainly) by four approaches: the comparison of sizes and shapes of chromosomes at metaphase I, the study of the heteropycnosis of particular chromosomal regions, chiasma formation on homologous regions at meiosis and comparative studies in different groups (White 1940a,b, 1941a, b, 1960, 1973; Castillo et al. 2010). Obviously the usefulness of this approach is limited, but White's contributions laid the foundations of further studies on the evolution of sex chromosomes.

How did two standard homologous autosomes become transformed into a pair of sex chromosomes with sex-determining 
properties? Darlington (1958) and Ohno (1967) suggested that the evolutionary pathway from an autosome to a sex chromosome could start by a para- or pericentric inversion (however, see below) of one of the homologous autosomes. The heterozygous inversion would restrict meiotic crossing over and recombination between the proto-sex chromosomes containing sex-determining genes, allowing for a progressive differentiation of the once homologous pair, while maintaining a synaptic region to allow chiasma formation and proper meiotic segregation. The process, if selected for, could constitute a crucial step in sex-chromosome evolution because lack of recombination allows evolutionary meiotic isolation, and accumulation of sex-linked and sex-limited genes and, eventually, sex determinants in the new heteromorphic sex chromosomes. The process of differentiation and avoidance of crossing over in the heterogametic sex may reach two extreme conditions: the complete abolition of synapsis between sex chromosomes (either in simple or multiple systems) and segregation through either 'touch and go' or 'distance' pairing, or the complete elimination of the Y chromosome, as in most Orthoptera and Nematoda (Cooper 1946, John \& Lewis 1965). The concept of 'erosion of the $\mathrm{Y}^{\prime}$ was coined by Darlington (1958) to account for the evolutionary gradual loss of genetic activity of the $\mathrm{Y}$ chromosomes, as seen in many Coleoptera and Heteroptera, where all stages in the diminution of the $\mathrm{Y}$, complete loss of homology with the $\mathrm{X}$, and its eventual disapearance, can be observed. But the process seems never to have reached this extreme in mammals and other vertebrates, where true XX/XO sytems do not occur [White 1960; although a few bizarre sex-chromosome mechanisms with XO individuals are known (Graves 2002, Just et al. 2002)], indicating fundamentally different strategies of sex-chromosome function in both groups.

At this point it is worthwhile to indicate that three related processes involving homologous chromosomes occur during early meiotic division: pairing, synapsis, and crossing over. The terms 'pairing' and 'synapsis' are frequently confused, but they refer to two different kinds of events: pairing refers to the recognition and alignment of homologous chromosomes succeeded by synapsis mediated by the formation of the synaptonemal complex. The relationship between synapsis and crossing over has been controversial, but in Orthoptera it is known that recombination events precede synapsis (Viera et al. 2010).

The concept of progressive evolutionary differentiation of newly arisen sex chromosomes should not be mistaken for White's (1941b) 'principle of evolutionary isolation of the $\mathrm{X}^{\prime}$ : this proposes that the $\mathrm{X}$ chromosome (in $\mathrm{XO} / \mathrm{XX}$ animal groups) becomes progressively isolated from the autosomes through a series of structural changes. White's hypothesis was based on the scarcity of data at that time reporting upon structural rearrangements between the X chromosome and autosomes. Presently we know that the facts are otherwise: many cases occur of X-autosome translocation and genetic traffic at the molecular level between sex chromosomes and autosomes, known especially in the Orthoptera Saltatoria (and other taxa, see below). However, White's contribution to the origin and evolution of sex chromosomes was substantial, in his identification of processes of differentiation between neo-sex XY systems involving chromosomal rearrangements, heterochromatinization and loss of crossing-over potential, a problem also addressed by the great South American cytologist Francisco A. Sáez (1898-1976) (Sáez 1963).

In recent years the analysis of the origin and evolution of sex chromosomes has benefited from a wealth of new and powerful tools (Kaiser \& Bachtrog 2010). At the molecular level it is known that evolution of sex chromosomes is accompanied by the degeneration of genes on the $\mathrm{Y}$ chromosome and the accumulation of various classes of repetitive DNA sequences in nonrecombining regions (Charlesworth 1991, Hobza et al. 2006). Consequently, many theoretical studies focus on the forces that produce the morphological and genetic changes between the X and Y chromosomes, and especially, how abolition of recombination starts between a pair of homomorphic homologous chromosomes, and why suppression of crossing over leads to a process of "genetic degeneration" (Charlesworth et al. 2005, Nicolas et al. 2005).

A number of models of different taxa have been investigated in trying to understand the evolutionary steps of sex-chromosome evolution. Although this bibliography is too extensive to detail, one example is: the recent analyses in teleost (bony) fishes' sex chromosomes: they have not reached the limits of their differentiation and allow one to visualize the footprints of the evolutionary forces that drive the evolution of sex chromosomes (Charlesworth 2004). For instance, the perciform Lutjanus quinquelineatus' multiple sex system is in an initial stage of morphological sex-chromosome differentiation (Ueno \& Takai 2008).

Another example in plants, Silene latifolia (white campion) is being intensively studied to trace the initial "evolutionary strata" of sex-chromosome evolution (Nicolas et al. 2005, Kejnovsky et al. 2009, Hobza et al. 2007). It is considered that evolution of flowering plants with separate sexes (dioecy) from an ancestral hermaphroditic condition (gynodioecy), has been sometimes accompanied by the development of sex chromosomes; in this scenario Fragaria virginiana (wild strawberry) is an example of the youngest sex chromosomes in plants in an intermediate stage between gynodioecy and dioecy, providing a special opportunity to study sex chromosome genesis (Spiegler et al. 2008, Moore 2009). Similarly, studies in species of Populus (aspen) show the location of a gender-determination locus, and the possible mechanism that causes and reinforces the suppression of crossing over (Yin et al. 2008). In invertebrates, as for several Drosophila species, study of neo-sex chromosomes has revealed empirical data of the first stages of degeneration (Nicolas et al. 2005).

The former biological models share a common feature: their chromosomal sex-determination systems are evolutionarily recent. They are at the initial stages of sex-chromosome differentiation, or in the middle of the differentiation process. The best-studied models of sex chromosomes (in mammals and Drosophila melanogaster) are very ancient and signs of their evolutionary origin are difficult to observe (Charlesworth \& Charlesworth 2000). Recently evolved systems allow one to follow the changes step by step, and also to infer the mechanisms and factors that lead sex chromosomes to take different evolutionary tracks. Presently, with modern molecular methods, it is feasible to characterize the sex-determining region in the genome, as demonstrated in mammals, fishes, plants and other model organisms (Charlesworth 2004; Hobza et al. 2006, 2007). For example, Hobza et al. (2006, 2007) combined results from physical mapping of sex-linked genes, using the polymerase chain reaction on microdissected arms of the Silene latifolia X-chromosome, and fluorescence in situ hybridization to evidence tandem repeats accumulated on the Y chromosome, and to propose an origin for sex chromosomes in this species.

Theory predicts that sex-chromosome evolution and the differentiation process could start with the emergence of a sex-determining gene in a pair of ordinary autosomes, with one allele determining male individuals and another, females; or better, the proto-sex chromosomes carry two sex-determining genes that cause male and female sterility on the proto-X and proto-Y chromosomes respectively (the former are 'two-factor models') (Charlesworth 2002, Charlesworth et al.2005). In this and other models, abolition of recombination involving nearby sex-determining genes is essential for driving the XY divergence process (Rice 1987, Charlesworth 2004, Charles- 
a)

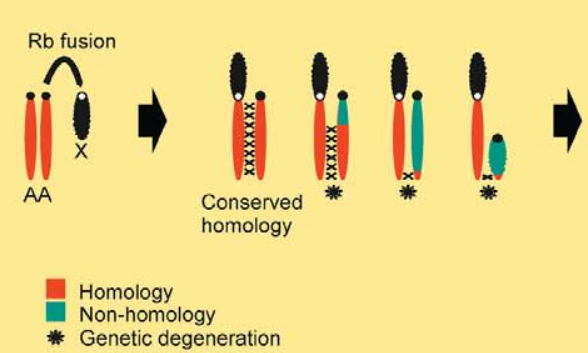

b)

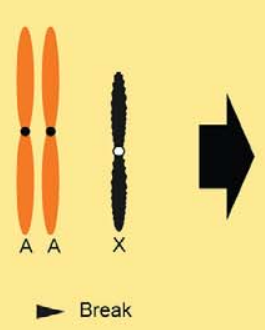

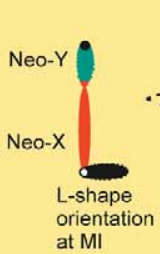
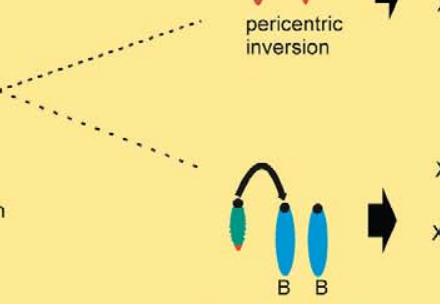

Fusion between the Neo-Y and a second autosome
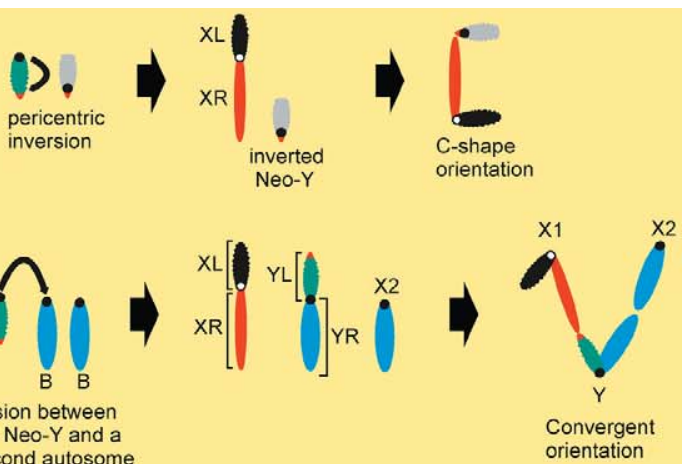

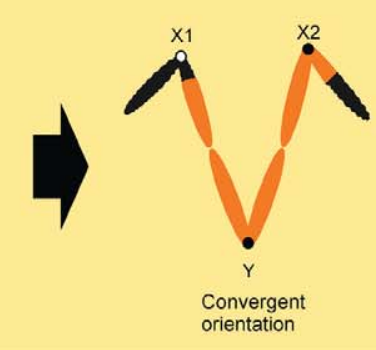

Fig. 1. Schematic view of neo-sex chromosome formation produced by translocation of the Robertsonian fusion type. a) Centric fusion between an autosome (A) and the X chromosome. In a recently arisen rearrangement, the XR and the neo-Y still conserve the homology (indicated in red). From the latter situation in the neo-Y begins a genetic degeneration, with consequent loss of homology (indicated in green). Other chromosomal restructurations (as a pericentric inversion, shown in gray) could become established in the neo-Y, so a C-shaped orientation is observed at metaphase I. A second Rb translocation event could occur between the neo-Y and another autosome, giving rise to a neo- $\mathrm{X}_{1} \mathrm{X}_{2} \mathrm{Y}$ complex sex-chromosome system (indicated in blue). b) Origin of mantid complex sexchromosomic mechanism in one step from an XO-XX sex system. For color version, see Plate I.

worth et al. 2005, Kejnovsky et al. 2009, Kaiser \& Bachtrog 2010). Restricted crossing-over near the sex-determining region reduces the frequencies of gametes with "wrong alleles" and the accumulation of genes that will have a selective advantage and hence be favored by selection (Charlesworth 2004).

As indicated above, nonrecombining regions are thought to have been formed as a result of chromosomal rearrangements (or local inhibitors of recombination) in evolving sex chromosomes, as they contribute to the suppression of crossing over via synaptic failure, precluding intrachromosomal recombination (Hobza et al. 2004, Hoffmann \& Rieseberg 2008). Thus, inversions and translocations added to modifiers of local cross-over rates, could reduce intrachromosomal recombination between future $\mathrm{X}$ and $\mathrm{Y}$ chromosomes (Charlesworth et al. 2005). In mammalian sex chromosomes, a series of Y inversions disrupting X-Y recombination have been reported (Lahn \& Page 1999); in plants such as Silene latifolia, Y chromosome evolution involved two large inversions, one paracentric and one pericentric (Hobza et al. 2007). In S. latifolia sex chromosomes, both reduction of recombination and $\mathrm{Y}$ degeneration may be presently in progress (Nicolas et al. 2005). The suppression of recombination between proto-sex chromosomes favors further degeneration of the Y chromosome, which can accumulate by different processes, deleterious mutations and repetitive sequences, the latter either by eliminating the possibility of unequal crossing over or through the accumulation of transposable elements (Charlesworth 2002).

\section{Sex chromosome systems}

Charlesworth (2002) has indicated that a neo-X/neo-Y chromosome pair formed by fusion between an autosome and a sex chromosome is an excellent model for studying the processes involved in Y chromosome degeneration. In fact, modern studies in Drosophila species with neo-sex chromosomes have been useful to test a number of hypotheses regarding sex-chromosome differentiation (Bone \& Kuroda 1996, Bachtrog \& Charlesworth 2000, Charlesworth \& Charlesworth 2000, Marin et al. 2000, Mahesh et al. 2001). However, neo-sex chromosome systems were first discovered and studied in acridomorph grasshoppers and mantids before the molecular era of genetics, and much insight was gained from these early investigations into the processes of sex chromosome origin and evolution (McClung 1914, 1917; King \& Beams 1938; Helwig 1941, 1942; King 1950).

Neo-sex chromosomes were first described by McClung (1905) in Hesperotettix speciosus (Melanoplinae), Mermiria bivittata (Gomphocerinae) and Anabrus sp. (Tettigoniidae); in McClung's words: 'Here [in Mermiria] it is found that one of the tetrads has become united end to end with the accessory chromosome so that the planes of their longitudinal division are coincident'.

However, the first comparative analysis of multiple chromosome mechanisms in invertebrates (mostly insects although only one grasshopper species was included), was published by White (1940a). Although the paper is mainly about multiple systems, a discussion of simpler neo-XY mechanisms in Acrididae was also included. Here, White coined the term 'neo- $\mathrm{Y}^{\prime}$ for a newly arisen $Y$ chromosome. White also proposed a terminology, still in use, to describe the chromosome arms of recently evolved neo-X and neo-Y chromosomes: the autosomal arm of neo-X, which shares homology with the neo-Y, is referred to as XR, while XL is the arm derived from the original $X$ chromosome fused to an autosome (Fig. 1a). This nomenclature is strictly applicable to simple centric fusion-derived neo-XY systems. In the case of multiple $\mathrm{X}_{1} \mathrm{X}_{2} \mathrm{Y} / \mathrm{X}_{1} \mathrm{X}_{1} \mathrm{X}_{2} \mathrm{X}_{2}$ sex-chromosome determination systems, the neo- $X_{1}$ is formed by the $\mathrm{X}_{1} \mathrm{~L}$ and the $\mathrm{X}_{1} \mathrm{R}$ arms. The neo-Y is now bi-armed, formed by the YL limb, while the other arm, the YR, shares homology with the neo- $\mathrm{X}_{2}$ (Fig. 1b) (White 1940a,b). White interpreted the formation of these neosystems in terms of what are now described as 
Robertsonian translocations (or centric fusions), first described by Robertson (1916) in autosomes of several Orthoptera (Fig. 1).

It is important to remark that neosystems usually originate through centric fusions, which are the commonest form of visible chromosomal rearrangement in animals and have special intrinsic properties. At least in the Orthoptera, where centric fusions are a frequent mechanism of chromosome change (John \& Hewitt 1968, John \& Freeman 1975, John 1983), fusions produce an instantaneous shift of proximal chiasmata towards distal locations in pericentromeric regions (Bidau 1990), creating recombination-free regions. Thus centric fusions, unlike tandem fusions (see below), are in a sense 'pre-adapted' to an existence as part of a neo-XY mechanism. This is because besides reducing crossing over between homologous partners, centric fusions do not produce in principle, serious synaptic problems. Also previous distal chiasma localization may determine that, from its origin, the neo-Y and $\mathrm{XR}$ will experience reduced crossing over. Both factors can create tight linkage between the sex chromosome and genes that are favorable in the heterogametic sex (Charlesworth et al. 2005). Finally, the sizes of chromosomes (i.e., $\mathrm{X}$ and the autosome) involved in the fusion are important in determining the symmetry of the new meiotic configuration and thus meiotic orientation and segregation, since effective intercentromeric distance is relevant in this context (Mirol \& Bidau 1992).

Within this framework White (1940a, 1941a) anticipated that changes due to structural rearrangement begin with the building up of a differential region around the centromere of the neo-Y in species of praying mantids with $\mathrm{X}_{1} \mathrm{X}_{2} \mathrm{Y} / \mathrm{X}_{1} \mathrm{X}_{1} \mathrm{X}_{2} \mathrm{X}_{2}$ sex chromosome mechanisms (by successive rearrangements, Fig. 1). In a later stage, a number of structural changes become fixed on the neo-Y; thus, that region loses homology with its autosomal counterpart on the neo-X or neo-X and a large crossover-free region ensues. This region, according to White (1940a,1941a), could house male-limited Y-linked genes (and also deleterious mutations). Of course, now we know that changes other than structural aid the differentiation of the neo-Y, such as accumulation of noncoding sequences and heterochromatinization (see below).

Although centric fusions have been especially relevant in the generation of neo-sex chromosomes in the Orthoptera and allies, a few exceptions are known where other rearrangements have been involved in the production of the new sex chromosomes, such as tandem fusions in some grasshoppers (White et al. 1967, White 1985, Bidau \& Martí 2002) or whole-arm reciprocal translocations in mantids (White1941a).

Apparently in the Orthoptera, Mantodea, Phasmatodea, Grylloblattodea and Blattodea, the $\mathrm{XO} / \mathrm{XX}$ condition is the primitive state, because the vast majority of species show this sex-chromosome system, indicating that evolutionary reversion from an $\mathrm{XY} / \mathrm{XX}$ mechanism occurred in the common ancestors of these groups (White1940a, 1973, 1976; Hughes-Schrader 1947; Hewitt 1979). However, the continuous emergence of neo-XY/XX or more complex systems in all of these groups is puzzling (White 1940a, 1941a, 1973; Hewitt 1979).

Neo-sex and multiple sex-chromosome systems have been reported in a wide array of animal groups other than the Orthoptera and details of their formation strongly depend on the nature of the involved sex and autosomal chromosomes. For example, in Acridoidea, with basic telocentric karyotypes (see below), centric fusions produce neo-XY/neo-XX systems (Fig. 1a) and multiple systems of the $\mathrm{X}_{1} \mathrm{X}_{2} \mathrm{Y} / \mathrm{X}_{1} \mathrm{X}_{1} \mathrm{X}_{2} \mathrm{X}_{2}$ type arise through fusion in a second evolutionary event (Fig. 1a). In praying mantids however, since the basic karyotype (including the primitive $\mathrm{X}$ ) is metacentric, unlike the Orthoptera, a translocation between the $\mathrm{X}$ and an autosome instantaneously produces a multiple system (White 1941a) (Fig. b). A discussion on the mode of origin of mantid multiple systems can be found in del Cerro et al. (1998).

In the Dermaptera, multiple systems have been related to possible polyploidy, although this interpretation is doubtful (Goldschmidt 1949). In some Coleoptera, amazingly complex multiple asynaptic sex chromosomes have evolved, but in many cases their origin is difficult to explain (Smith \& Virkki 1975). Frequent neo-XY and multiple sex systems have evolved in the Heteroptera and the holokinetic nature of heteropteran chromosomes implies different modes of origin and behavior of these chromosomes during meiosis (Bressa et al. 2009). A very complex system of fusion-derived neo-sex chromosomes occurs in the spider Delena cancerides (Rowell 1990). In fishes, multiple systems have been derived, mainly by fusion of an original Y (of a primitive XY system) with an autosome (Ueno \& Takai 2008, Kitano et al. 2009). In Monotremata, the existence of amazingly complex sex chromosomes (males of the platypus have 5 $\mathrm{X}$ and $5 \mathrm{Y}$ chromosomes originated through several translocations) poses interesting problems of dosage compensation (Gruetzner et al. 2006, Deakin et al. 2008). In eutherian mammals, with a standard $\mathrm{XY} / \mathrm{XX}$ system, a few cases of derived multiple-sex chromosomes are known and are usually of the $\mathrm{XY}_{1} \mathrm{Y}_{2} / \mathrm{XX}$ type; but some, as in the black muntjac, reveal an extremely complex origin (White 1960, Zhou et al. 2008).

\section{Neo-sex chromosome systems in Acridoidea}

Acridoid grasshoppers included in the Cryptosacci section of Roberts (1941) display an apparent karyotypic stability, with the vast majority of species exhibiting a modal karyotype $(2 n=23 \hat{\jmath} /$ 24 ; $F N=23 / 24$ ) with acrotelocentric chromosomes and an XO/XX sex-determination mechanism. Section Chasmosacci (that includes only Pyrgomorphidae and Pamphagidae) has a basic karyotype of $2 n=19 \hat{O} / 20$; $F N=19 / 20$, all chromosomes acrotelocentric. This constancy is only morphological, since DNA content varies widely between species with the same chromosome number (John \& Hewitt 1966, Rees et al. 1974) owing to for example, different heterochromatin content (John \& King 1977). This stable pattern of a basic telocentric karyotype has only been modified in the Ommexechidae, in which the largest autosomal pair underwent a pericentric inversion in the ancestor of the family, transforming it into a bi-armed element in the majority of species (Mesa \& Ferreira 1977).

However, in many cases variations on the modal karyotype have occurred in evolution. A number of Nearctic and Palearctic gomphocerine genera (Chorthippus, Chloealtis, Myrmeleotettix, Stauroderus, Stenobothrus, etc.) are $2 \mathrm{n}=17 / 18$, with three fixed-centric fusions, very probably derived from a common ancestor (Hewitt 1979). Many South American melanopline species show fixed-centric fusions (Mesa et al. 1982). In other cases, reduction in chromosome number occurred with no morphological variation of chromosomes, presumably due to tandem fusions (i.e., Dichroplus pratensis with a basic all-telocentric karyotype of $2 n=19 / 20)$. Karyotype variation may also be intraspecific due to polymorphisms for centric fusions [i.e., Dichroplus pratensis; Bidau \& Martí (2002)] or pericentric inversions [i.e., Trimerotropis spp; Guzmãn \& Confalonieri (2010)].

B- chromosomes, a usual form of chromosome-number variation in grasshoppers, are parasitic entities that lie outside the scope of this review (Camacho et al. 2000). An important component of chromosome variation in Orthoptera, and especially Acridoidea, is constituted of course, by neo-sex chromosomes.

Neo-sex chromosome systems have independently appeared in almost all major groups of Orthoptera, both Ensifera and Caelifera. A number of cases have been identified in the Tettigoniidae (White et al. 1967; Ferreira 1969, 1976; Mesa et al. 2010), Gryllidae (Mesa 
\& García-Novo 2001), Gryllotalpidae (Steopoe 1939), Gryllacrididae (Mesa et al. 1969, Mesa \& Mesa 1971) and of course, in the Acridomorpha, the best cytogenetically studied orthopteran group in this respect (Hewitt 1979, Mesa et al. 1982).

However, some curious asymmetries in the distribution of neosex systems exist. For example, not a single case of neo-system has been reported in the neotropical Proscopiidae (Proscopioidea) among 29 species from 8 genera, although fusion rearrangements of the 9 acrocentric standard pairs of autosomes have been frequent (Mesa \& Ferreira 1978). The same seems to occur in the majority of eumastacid subfamilies (White 1968, 1979, 1975; Mesa \& Ferreira 1981) with the exceptions of one species of African Thericleinae (White 1965), one of the Australian Gomphomastacinae (White 1968), and the extraordinary case of the Australian Morabinae. More than thirty different neo-XY mechanisms are known to have evolved among 200 studied species (probably in eleven independent events), six of which have undergone the further transformation in to an $X_{1} X_{2} Y$ system (White 1957, 1973; Mesa et al. 1982).

It is in the Acridoidea that the vast majority of cases of neo-sex chromosomes have been described (White 1973, Hewitt 1979, Mesa et al. 1982, Tables 1, 2). However, asymmetric distribution of neo-sex chromosomes also occurs within the superfamily. In Ommexechidae, 5 out of 20 species acquired independent neo-XY systems (Mesa \& Ferreira 1977; Mesa et al. 1990, 2001). Only 3 out of 47 studied species of Romaleidae (6\%) have neo-XY chromosomes (Mesa et al. 1982). Within the Acrididae, the large Melanoplinae subfamily is by far the most studied cytogenetically, and also that in which most cases of derived sex-chromosome systems have been described (Hewitt 1979, Mesa et al. 1982, Table 1, 2). Neotropical melanoplines (Fig. 3a-d) in particular, present special chromosomal features and include a large number of species displaying reductions in chromosome number, mainly due to the occurrence of centric fusions; but other rearrangements have also played a role in karyotype restructuration.

An example of the extreme divergence from the ancestral $2 \mathrm{n}$ and $\mathrm{FN}$ is the case of Dichroplus silveiraguidoi $(2 \mathrm{n}=8$, neo-XY, FN=13/14) (Sáez 1856a,b 1957; Cardoso et al. 1974; Sáez \& Pérez-Mosquera 1977; Cardoso \& Dutra 1979), the lowest chromosome number among Orthoptera. Robertsonian fusions between X chromosomes and autosomes (X/A fusion) have occurred many times in the evolutionary history of South American Melanoplinae which exhibit an amazing diversity of neo-XY chromosome systems (Mesa et al. 1982, Bidau \& Martí 2000, Mesa et al. 2001, Colombo et al. 2005, Castillo et al. 2010, this paper). The incidence of neo-sex chromosomes in other neotropical subfamilies is much lower, or even zero (i.e., Gomphocerinae, Acridinae, Leptysminae, Ommatolampinae, etc.), with the sole exception of the Copiocerinae, where all species from both genera of the tribe Aleuasini (Aleuas and Zygoclistron) are neo-XY, probably deriving from a common ancestor (Table 2).

Although most described neo-sex systems outside the neotropics also belong to Melanoplinae, their frequency per the total number of species represented in these two geographic parts is much lower (Mesta et al. 1982). The geographic discrepancy in neo-sex chromosome frequencies is most obvious when Australian Acridoidea are considered. Of more than 100 species studied, only four belonging to two genera (John \& Freeman 1975, Mesa et al. 2006) show neo-XY systems (Table 1). Furthermore, the vast majority of Australian species show standard $2 \mathrm{n}=23 \hat{\jmath} / 24$ ㅇ karyotypes. Within the Chasmosacci, a number of cases of neo-XY systems has recently been reported in the Pamphagidae (Table 1), but none in the Pyrgomorphidae.

In most cases, complete information about the origin, structure and meiotic behavior of neo-sex chromosomes is scarce in species of Acrididae, including neotropical taxa. However, the background of neo-XY/XX precedents left by pioneering cytologists like Michael White, Alejo Mesa and Francisco Sáez (the latter two for neotropical Orthoptera), is huge, and allows present-day researchers to focus on unresolved questions and also to use these species as experimental models to infer possible evolutionary paths of sex chromosome evolution.

\section{Evolution of neo-sex chromosomes in Acridoidea}

Following the proposed pathway of sex-chromosome evolution [establishment of a sex-determining region, recombination suppression, accumulation of repeats/heterochromatinization, degeneration of genes, and shrinkage by deletion/structural rearrangement (Kejnovsky et al. 2009)], grasshopper neo-XY chromosome systems fall within a continuum of evolutionary situations. They show at one end a small degree of differentiation, where the neo-Y still conserves high homology with the XR arm of the neo-X; on the other end there is almost complete loss of homology between $\mathrm{Y}$ and XR, evidenced by an extremely reduced synaptic zone, and by the accumulation of repetitive heterochromatic sequences that produces heterochromatinization of the Y and eventually, of XR (Sáez 1963, Cardoso \& Dutra 1979). Between these two cases, a spectrum of neo-sex chromosome conditions revealing different evolutionary strata, are found (White 1973, Hewitt 1979, Castillo et al. 2010). Once a neo-XY system has arisen by centric fusion, it may undergo a further conversion into an $\mathrm{X}_{1} \mathrm{X}_{2} \mathrm{Y}$ system through a Y-autosome fusion, if a second pair of teleo/acrocentric autosomes is available to become incorporated into the sex-chromosome mechanism (White 1973, Hewitt 1979, Castillo et al. 2010).

Recently arisen simple neo-sex chromosome systems will be initially represented by a sex pair, which still conserves almost the totality of the homology, synaptic ability and possibility of free recombination along the fused autosome (XR) and its homologue - now the neo-Y (since centric fusions tend to preclude proximal recombination, proximal chiasmata are nevertheless rare; however, exceptions do occur).

Examples of this stage are Mariacris viridipes, Tetrixocephalus willemsei, and Podisma pedestris (Fig. 2b, Tables 1, 2). The ommexechid Neuquenina fictor is the most notable case, since XR and Y may form up to 4 chiasmata (Mesa 1961, Table 2). Spontaneous neo-XY mutants are also expected to behave this way as in Paracyptera kheili and Leiotettix sanguineus (Tables 1, 2). In some cases, however, interstitial chiasmata may not be formed, due to a former strong distal localization of chiasmata, as in the spontaneous mutant of Baeacris punctulatus (Fig. 2a, Table 1). A further stage is represented by Dichroplus obscurus and species of Tolgadia, where neo-Y-XR synapsis is basically complete, but the proximal portion of neo-Y is heterochromatic. Chiasma formation is essentially distal but occasional interstitial chiasmata are formed (Mesa 1971, John \& Freeman 1976, Bidau \& Martí 2001) (Tables 1, 2).

At the other end of the spectrum, many species show neo-XY features that indicate their advanced stage: massive heterochromatinization of the neo-Y (and sometimes of part of the XR), synaptic failure, exclusive distal meiotic association of both sex chromosomes and complex neo-Y structural rearrangements. An example of this 'terminal?' stage is Ronderosia bergi. All known Ronderosia species exhibit neo-XY or neo- $\mathrm{X}_{1} \mathrm{X}_{2} \mathrm{Y}$ sex systems (Fig. 2c, d, Table 2). In $R$. bergithe neo-Y is almost completely heterochromatic, late-replicating and C-band positive and has undergone a pericentric inversion that involved more than $90 \%$ of the original chromosome length-which effectively limits recombination and synapsis to the distal end of XR and the short arm of neo-Y (Díaz \& Sáez 1968, Cardoso \& Dutra 1979) (Fig. 2d). Other Ronderosia species also show highly heterochromatic neo-Y chromosomes and strict terminal association with 
Table 1. Non-neotropical grasshopper species (Acridoidea) with neo-sex chromosome systems.

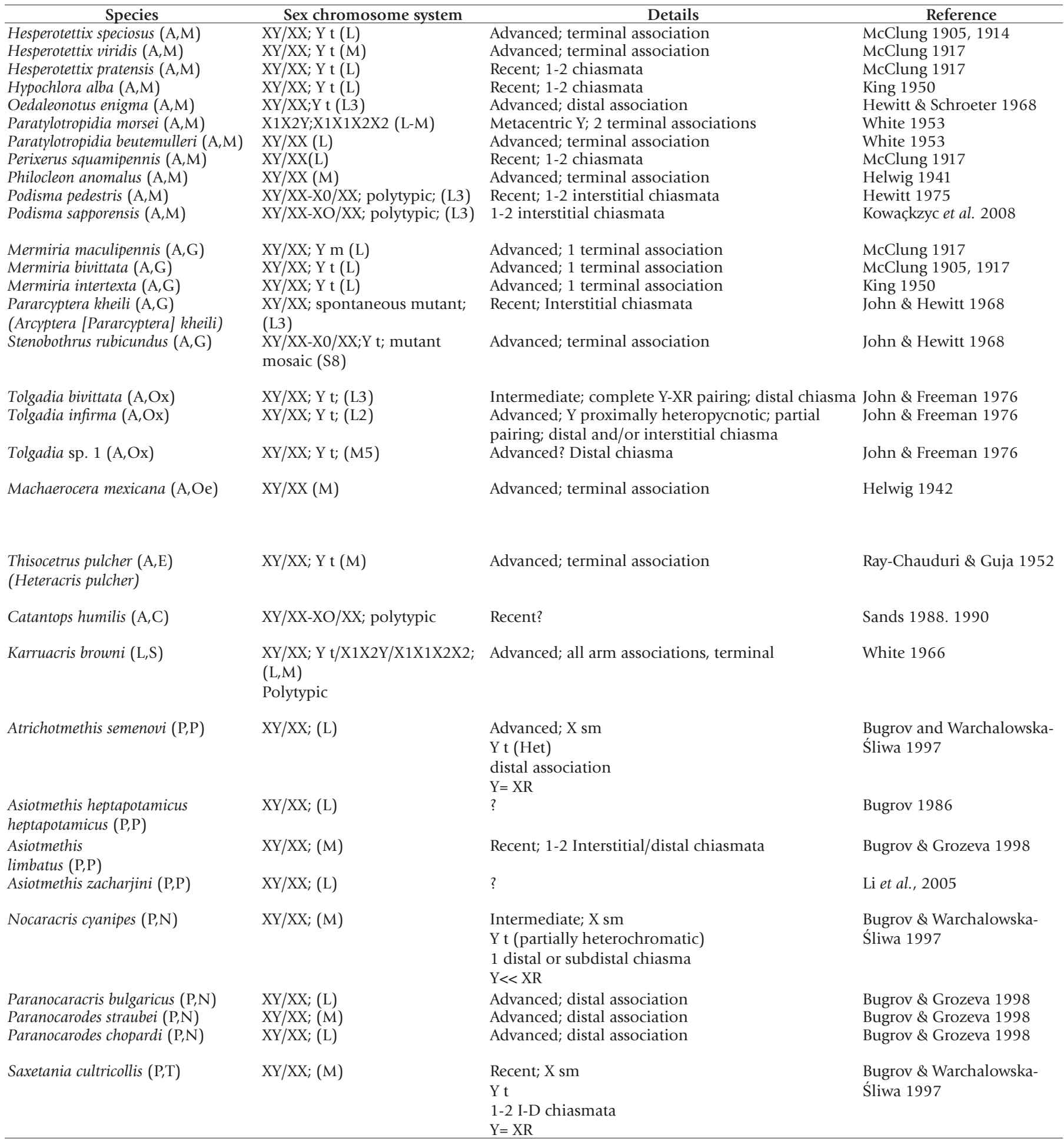

$\mathrm{L}, \mathrm{M}$ and S, refer to the size of the autosome/s involved in the formation of the neo-sex system; in some cases the exact autosome is known, in others it was estimated from published illustrations. Recent, Intermediate, Advanced, Spontaneous: these categories were arbitrarily assigned considering information on pairing, chiasma formation, heterochromatinization, restructuration, and frequency when available. Presence of chiasmata, terminal, and distal association always refer to the neo-sex chromosome arms. Taxonomy- $\mathrm{A}=\mathrm{Acrididae}$ : $\mathrm{C}=\mathrm{Catantopinae}, \mathrm{E}=\mathrm{Eyprepocneminae}$, $\mathrm{G}=$ Gomphocerinae, $\mathrm{M}=$ Melanoplinae, $\mathrm{Oe}=$ Oedipodinae, $\mathrm{Ox}=$ Oxyinae. $\mathrm{L}=$ Lentulidae: $\mathrm{S}=$ Shelforditinae. $\mathrm{P}=\mathrm{Pamphagidae:} \mathrm{N}=\mathrm{Nocarodesinae}, \mathrm{P}=$ Prionotropisinae, $\mathrm{T}=$ Tropidaucheninae. 
Table 2. Neotropical South American grasshoppers (Acridoidea) with neo-sex chromosome systems. 2n M/F = diploid number of chromosomes in males and females; $\mathrm{FN} \mathrm{M} / \mathrm{F}=$ Fundamental Number (number of chromosome arms) in males and females; male chromosome number (2n $\mathrm{M}$ ); male and female fundamental number (FN M/F). recent, intermediate, advanced, spontaneous: these categories were arbitrarily assigned considering information on pairing, chiasma formation, heterochromatinization, restructuration, and frequency when available. Other or multiple re-arrangements involved, refer to further structural change (other than heterochromatinization), after neo-sex chromosome formation. L-, C-, J-shaped refer to the appearance of the neo-XY bivalent when disjunctionally co-oriented at male metaphase I. C-shaped configurations result in all cases from a pericentric inversion of the neoY; J-shaped configurations may result from neocentric activity of the neo-Y; Y-shaped configuration was only observed in D. vittatus as a consequence of neocentric activity of XL; X1X2Y sex trivalents usually show a V-shaped disjunctional configuration. Morphology: $\mathrm{m}=\mathrm{metacentric}$, sm= submetacentric. $\mathrm{st}=$ subtelocentric, $\mathrm{t}=$ telocentric; $\mathrm{L}, \mathrm{M}$ and $\mathrm{S}$, refer to the size of the autosome/s involved in the formation of the neo-sex system; in some cases the exact autosome is known, in others it was estimated from published illustrations. Site, refers to the actual geographic coordinates of the specimens studied by the authors; other localities can be found in the cited literature. Geographical distribution is presented as the known latitudinal range of each species.

\begin{tabular}{|c|c|c|c|c|c|c|c|}
\hline $\begin{array}{l}\text { Subfamily } \\
\text { Species }\end{array}$ & 2n M/F & $\begin{array}{c}\mathrm{FN} \\
\mathrm{M} / \mathrm{F}\end{array}$ & Details & Morphology & Site & $\begin{array}{l}\text { Geographical } \\
\text { distribution } \\
\text { (long: from, to) }\end{array}$ & Reference \\
\hline \multicolumn{8}{|l|}{ Melanoplinae } \\
\hline Baeacris punctulatus & $\begin{array}{l}22 / 22- \\
23 / 24\end{array}$ & $23 / 24$ & $\begin{array}{l}\text { spontaneous X/A fusion; } \\
\text { L-shaped }\end{array}$ & X m, Y t; (L3) & $32^{\circ} 43^{\prime} \mathrm{S}, 65^{\circ} 21^{\prime} \mathrm{W}$ & & This paper \\
\hline Atrachelacris unicolor & $22 / 22$ & $23 / 24$ & $\begin{array}{l}\mathrm{XY} / \mathrm{XX} \text {; intermediate; } \\
\text { L-shaped }\end{array}$ & $\mathrm{X} \mathrm{m,Y} \mathrm{t;} \mathrm{(M5)}$ & $\begin{array}{l}24^{\circ} 42^{\prime} \mathrm{S}, 65^{\circ} 26^{\prime} \mathrm{W} \\
25^{\circ} 28^{\prime} \mathrm{S}, 57^{\circ} 2^{\prime} \mathrm{W} \\
30^{\circ} 43^{\prime} \mathrm{S}, 59^{\circ} 34^{\prime} \mathrm{W}\end{array}$ & $\begin{array}{l}17^{\circ} \mathrm{S} 43^{\circ} \mathrm{W} \\
40^{\circ} \mathrm{S} 66^{\circ} \mathrm{W}\end{array}$ & Mesa 1956 \\
\hline Dichroplus maculipennis & $22 / 22$ & $23 / 24$ & $\begin{array}{l}\mathrm{XY} / \mathrm{XX} \text {, advanced, other } \\
\text { rearrangements involved; } \\
\text { L/J-shaped }\end{array}$ & $\mathrm{X}$ m, Yt; (S? R?) & & $\begin{array}{l}29^{\circ} \mathrm{S} 52^{\circ} \mathrm{W} \\
43^{\circ} \mathrm{S} 69^{\circ} \mathrm{W}\end{array}$ & $\begin{array}{l}\text { Mesa et al. 1982, this } \\
\text { paper }\end{array}$ \\
\hline Dichroplus obscurus & 1818 & $23 / 24$ & $\mathrm{XY} / \mathrm{XX}$; recent; L-shaped & X m, Y t; (L1) & $27^{\circ} 26^{\prime} \mathrm{S}, 55^{\circ} 52^{\prime} \mathrm{W}$ & $\begin{array}{l}29^{\circ} \mathrm{S} 52^{\circ} \mathrm{W}, \\
38^{\circ} \mathrm{S} 62^{\circ} \mathrm{W}\end{array}$ & Saez \& Mosquera, 1971 \\
\hline Dichroplus porteri & $22 / 22$ & $23 / 24$ & $\mathrm{XY} / \mathrm{XX} ; ?$ & $\begin{array}{l}\mathrm{X} s \mathrm{sm}, \mathrm{Y} \mathrm{t} \text {; (M-S? } \\
\mathrm{R} ?)\end{array}$ & & $\begin{array}{l}34^{\circ} \mathrm{S} 71^{\circ} \mathrm{W} \\
41^{\circ} \mathrm{S} 73^{\circ} \mathrm{W}\end{array}$ & Mesa 1973 \\
\hline Dichroplus vittigerum & $18 / 18$ & $23 / 24$ & $\begin{array}{l}\mathrm{XY} / \mathrm{XX} ; \text { advanced. L/J- } \\
\text { shaped }\end{array}$ & $\mathrm{Xm}, \mathrm{Yt} ;(\mathrm{M} ?)$ & & $\begin{array}{l}36^{\circ} \mathrm{S} 70^{\circ} \mathrm{W} \\
45^{\circ} \mathrm{S} 69^{\circ} \mathrm{W}\end{array}$ & Mesa 1973 \\
\hline Dichromatos lilloanus & $21 / 22$ & $23 / 24$ & $\mathrm{X}_{1} \mathrm{X}_{2} \mathrm{Y} / \mathrm{X}_{1} \mathrm{X}_{1} \mathrm{X}_{2} \mathrm{X}_{2}$ & $\begin{array}{l}\text { X1 m, X2 t, } \\
\text { Y m; (L-L) }\end{array}$ & $\begin{array}{l}27^{\circ} 47^{\prime} \mathrm{S}, 55^{\circ} 13^{\prime} \mathrm{W} \\
27^{\circ} 9^{\prime} \mathrm{S}, 53^{\circ} 54^{\prime} \mathrm{W}\end{array}$ & $\begin{array}{l}30^{\circ} \mathrm{S} 57^{\circ} \mathrm{W} \\
27^{\circ} \mathrm{S} 52^{\circ} \mathrm{W}\end{array}$ & Mesa 1962 \\
\hline Dichromatos schrottkyi & $21 / 22$ & $23 / 24$ & $\mathrm{X}_{1} \mathrm{X}_{2} \mathrm{Y} / \mathrm{X}_{1} \mathrm{X}_{1} \mathrm{X}_{2} \mathrm{X}_{2}$ & $\begin{array}{l}\mathrm{X} 1 \mathrm{sm}, \mathrm{X} 2 \mathrm{t} \\
\mathrm{Y} \mathrm{m},(\mathrm{L}-\mathrm{L})\end{array}$ & $\begin{array}{l}26^{\circ} 42^{\prime} \mathrm{S}, 54^{\circ} 14^{\prime} \mathrm{W} \\
26^{\circ} 22^{\prime} \mathrm{S}, 54^{\circ} 12^{\prime} \mathrm{W} \\
26^{\circ} 42^{\prime} \mathrm{S}, 54^{\circ} 14^{\prime} \mathrm{W}\end{array}$ & $\begin{array}{l}25^{\circ} \mathrm{S} 53^{\circ} \mathrm{W} \\
26^{\circ} \mathrm{S} 54^{\circ} \mathrm{W}\end{array}$ & Mesa et al. 1982 \\
\hline Dichromatos corupa & $21 / 22$ & $23 / 24$ & $\mathrm{X}_{1} \mathrm{X}_{2} \mathrm{Y} / \mathrm{X}_{1} \mathrm{X}_{1} \mathrm{X}_{2} \mathrm{X}_{2}$ & $\begin{array}{l}\mathrm{X}_{1} \mathrm{~m}, \mathrm{X}_{2} \mathrm{t}, \mathrm{Ym} \\
(\mathrm{L}-\mathrm{L})\end{array}$ & & $\begin{array}{l}25^{\circ} \mathrm{S} 49^{\circ} \mathrm{W} \\
29^{\circ} \mathrm{S} 51^{\circ} \mathrm{W}\end{array}$ & Ferreira \& Mesa 2010 \\
\hline Dichromatos montanus & $21 / 22$ & $23 / 24$ & $\mathrm{X}_{1} \mathrm{X}_{2} \mathrm{Y} / \mathrm{X}_{1} \mathrm{X}_{1} \mathrm{X}_{2} \mathrm{X}_{2}$ & $\begin{array}{l}\mathrm{X} 1 \mathrm{~m}, \mathrm{X} 2 \mathrm{t} \\
\text { Y sm (L-M) }\end{array}$ & & $\begin{array}{l}22^{\circ} \mathrm{S} 44^{\circ} \mathrm{W}, \\
23^{\circ} \mathrm{S} 45^{\circ} \mathrm{W}\end{array}$ & Ferreira \& Mesa 2010 \\
\hline Eurotettix minor & $22 / 22$ & $23 / 24$ & XY/XX; L-shaped & & $26^{\circ} 10^{\prime} \mathrm{S}, 57^{\circ} 6^{\prime} \mathrm{W}$ & $\begin{array}{l}25^{\circ} \mathrm{S} 57^{\circ} \mathrm{W}, \\
26^{\circ} \mathrm{S} 57^{\circ} \mathrm{W}\end{array}$ & $\begin{array}{l}\text { Mesa et al. 1982, } \\
\text { Ferreira \& Mesa } 2010\end{array}$ \\
\hline Leiotettix pulcher & $22 / 22$ & $23 / 24$ & $\mathrm{XY} / \mathrm{XX} ; ?$ & $?$ & & $\begin{array}{l}25^{\circ} \mathrm{S} 65^{\circ} \mathrm{W}, \\
38^{\circ} \mathrm{S} 62^{\circ} \mathrm{W}\end{array}$ & $\begin{array}{l}\text { Mesa 1956, Mesa et al., } \\
1982\end{array}$ \\
\hline Leiotettix sanguineus & $\begin{array}{l}23 / 24- \\
22 / 22\end{array}$ & $23 / 24$ & $\begin{array}{l}\text { Two cytotypes X0/XX-XY/ } \\
\text { XX; L-shaped } \\
\text { Recent, interstitial I } \\
\text { chiasmata }\end{array}$ & $\mathrm{X} \mathrm{m}, \mathrm{Y} \mathrm{t}$; (L1) & & $\begin{array}{l}23^{\circ} \mathrm{S} 61^{\circ} \mathrm{W} \\
33^{\circ} \mathrm{S} 61^{\circ} \mathrm{W}\end{array}$ & Mesa \& Mesa, 1967 \\
\hline Mariacris viridipes & $20 / 20$ & $19 / 20$ & $\begin{array}{l}\mathrm{XY} / \mathrm{XX} ; \text { ? } \\
\text { Recent; interstitial } \\
\text { chiasmata }\end{array}$ & X st, Y t; (L1) & $24^{\circ} 56^{\prime} \mathrm{S}, 61^{\circ} 29^{\prime} \mathrm{W}$ & $\begin{array}{l}22^{\circ} \mathrm{S} 64^{\circ} \mathrm{W}, \\
27^{\circ} \mathrm{S} 65^{\circ} \mathrm{W}\end{array}$ & This paper \\
\hline Ronderosia bergi & $22 / 22$ & $23 / 24$ & $\begin{array}{l}\mathrm{XY} / \mathrm{XX} \text {; advanced; } \\
\mathrm{C} \text {-shaped; inversion } \\
\text { established in the neo-Y }\end{array}$ & X m, Y st (M.I) & $\begin{array}{l}25^{\circ} 25^{\prime} \mathrm{S}, 56^{\circ} 27^{\prime} \mathrm{W} \\
24^{\circ} 42^{\prime} \mathrm{S}, 65^{\circ} 26^{\prime} \mathrm{W} \\
25^{\circ} 35^{\prime} \mathrm{S}, 53^{\circ} 59^{\prime} \mathrm{W} \\
32^{\circ} 43^{\prime} \mathrm{S}, 65^{\circ} 21^{\prime} \mathrm{W}\end{array}$ & $\begin{array}{l}12^{\circ} \mathrm{S} 47^{\circ} \mathrm{W} \\
38^{\circ} \mathrm{S} 62^{\circ} \mathrm{W}\end{array}$ & $\begin{array}{l}\text { Mesa 1962, Castillo et } \\
\text { al. } 2010\end{array}$ \\
\hline Ronderosia dubius & $21 / 22$ & $23 / 24$ & $\mathrm{X}_{1} \mathrm{X}_{2} \mathrm{Y} / \mathrm{X}_{1} \mathrm{X}_{1} \mathrm{X}_{2} \mathrm{X}_{2}$ & $\begin{array}{l}\mathrm{X}_{1} \mathrm{sm}, \mathrm{X}_{2} \mathrm{t} \\
\mathrm{Ym} ;(\mathrm{L}-\mathrm{M})\end{array}$ & $27^{\circ} 26^{\prime} \mathrm{S}, 55^{\circ} 53^{\prime} \mathrm{W}$ & $\begin{array}{l}25^{\circ} \mathrm{S} 57^{\circ} \mathrm{W} \\
29^{\circ} \mathrm{S} 53^{\circ} \mathrm{W}\end{array}$ & $\begin{array}{l}\text { Mesa \& Mesa 1967, this } \\
\text { paper }\end{array}$ \\
\hline Ronderosia forcipatus & $21 / 22$ & $23 / 24$ & $\begin{array}{l}\mathrm{XY} / \mathrm{XX} \text {; intermediate; } \\
\text { L-shaped }\end{array}$ & $\mathrm{X}$ m, Y t (M4) & $27^{\circ} 25^{\prime} \mathrm{S}, 58^{\circ} 52^{\prime} \mathrm{W}$ & $\begin{array}{l}25^{\circ} \mathrm{S} 57^{\circ} \mathrm{W}, \\
33^{\circ} \mathrm{S} 64^{\circ} \mathrm{W}\end{array}$ & Castillo et al. 2010 \\
\hline
\end{tabular}


Table 2. Continued.

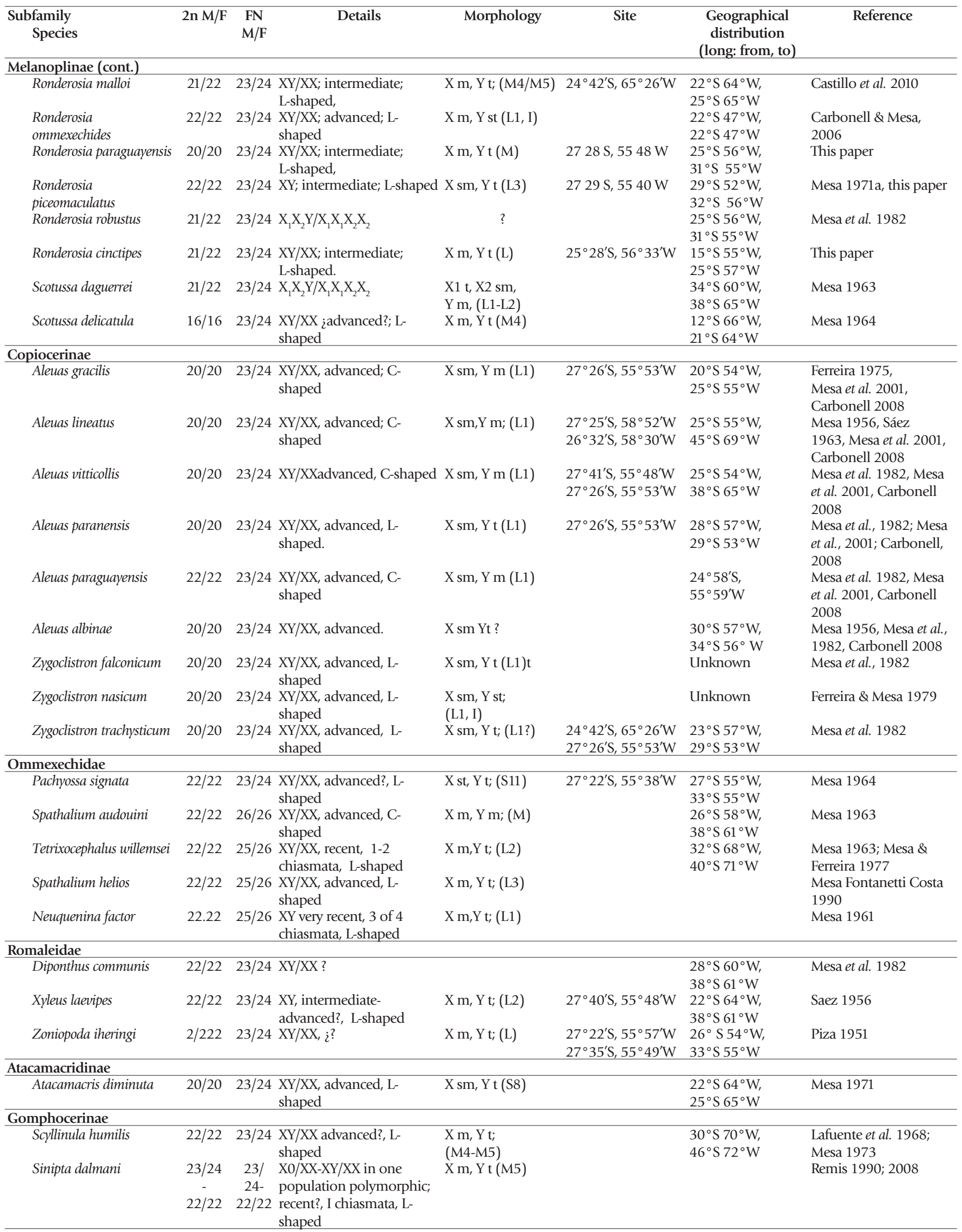


XR (Castilllo et al. 2010, Table 2).

Dichroplus silveiraguidoi (Table 2) is another example of a highly evolved neo-XY system. This species is unique in being $2 \mathrm{n}=8$ (see above) and the only one known in which the neo-X is telocentric, the neo-Y being very small and acrocentric (Sáez 1957). Due to this extraordinarily rearranged karyotype, it is very difficult to infer the evolutionary history of the sex chromosomes. Although the neo-Y is only partially heterochromatic, synapsis only occurs between its centromericend (short arm) and the distal heterochromatic portion of XR (Cardoso et al. 1974, Cardoso \& Dutra 1979).

Dichroplus vittatus (Table 2) has a complex neo-XY system which is not interpretable in standard terms. Bidau and Martí (2001) interpreted the origin of the neo-sex system as a tandem fusion of two original telocentricX chromosomes, followed by another tandem fusion with the small megameric bivalent and a further pericentric inversion of the neo-X. The remaining autosomal homolog resulted in the neo-Y chromosome. This model explains the extreme size difference between XR and neo-Y, the distal association between both elements, the existence of a neocentromere in XL and the very irregular male meiotic behavior of the sex bivalent (asynapsis, lagging, nondisjunction), as well as some peculiarities of the neo$\mathrm{X} /$ neo-X bivalent in female meiosis. In this species, it is difficult to say if the neo-sex pair is a highly evolved and degenerate one, or if its meiotic misbehavior is due to a recent origin, masked by the complexity of the rearrangements involved. However, presumably adaptive advantages may compensate for the potential negative heterosis of the neo-XY in males (Bidau \& Martí 2001). A closely related species, D. maculipennis, probably shows a similarly complex neo-XY system (Mesa et al. 2001; Castillo, Martí \& Bidau, unpub.). Other neotropical neo-XY species have not been studied in detail but probably follow the same general advanced pattern (Table 2).

We said above that multiple sex-chromosome systems of the neo- $\mathrm{X}_{1}$-neo- $\mathrm{X}_{2}$-neo-Y type (Fig. 1) are a further evolutionary path that neo-sex chromosomes may follow. Although much less frequent than typical neo-XY systems, all known cases belong to the Melanoplinae, and the majority correspond to neotropical species (8) of restricted geographic distribution (Mesa 1962b, 1963a; Mesa \& Mesa 1967; White 1973; Hewitt 1979; Mesa et al. 1982; Castillo et al. 2010a, Ferreira \& Mesa 2010; this paper; Table 2). Only two non-neotropical melanoplines, both from the genus Paratylotropidia, exhibit this type of mechanism (King \& Beams 1938, White 1957, Table 1). All neo- $\mathrm{X}_{1} \mathrm{X}_{2} \mathrm{Y}$ species belong to genera in which neo-XY mechanisms are frequent (i.e., Dichroplus, Ronderosia, Scotussa, Paratylotropidia), or all known species share this type of sex chromosomes (Dichromatos). Since $\mathrm{X}_{1} \mathrm{X}_{2} \mathrm{Y}$ mechanisms derive from previous $\mathrm{XY}$ systems through centric fusion of the neo-Y with a second autosome (the unfused element becoming $\mathrm{X}_{2}$, see above), it is probable that all known cases have originated from advanced XY systems. This is reasonable, considering that the probability of rapid occurrence of two sequential fusions is very low. Almost all systems share a characteristic extreme distal localization of chiasmata in both arms, thus recombination is not only restricted between $\mathrm{X}_{1} \mathrm{R}$ and $\mathrm{YL}$, but also between $\mathrm{YR}$ and $\mathrm{X}_{2}$. Some examples of this sex-chromosome system follow.

Leiotettix politus (Mesa \& Mesa 1967).- Although described as a $\mathrm{XY}-\mathrm{XX} / \mathrm{X}_{1} \mathrm{X} 2 \mathrm{Y}-\mathrm{X}_{1} \mathrm{X}_{1} \mathrm{X}_{2} \mathrm{X}_{2}$ polymorphism, the only individual carrying multiple sex chromosomes was probably a spontaneous mutant. In this male, complete synapsis occurred between YR and $\mathrm{X}_{2}$ wth interstitial chiasma formation. YL is heterochromatic (as in the $\mathrm{XY}$ individuals) and only a distal association occurs between it and $\mathrm{X}_{1} \mathrm{R}$.
Ronderosia dubius (Mesa \& Mesa 1967). - This is a peculiar case because during pachytene, $\mathrm{X}_{2}$ and $\mathrm{YR}$ are fully synapsed. $\mathrm{YL}$ is completely heterochromatic, but YR and $\mathrm{X}_{2}$ are not. However, despite full pairing between $\mathrm{YR}$ and $\mathrm{X}_{2}$, association is always distal. The same association usually happens between $\mathrm{X}_{1} \mathrm{R}$ and $\mathrm{YL}$ and one individual showed $>25 \%$ asynapsis between $\mathrm{X}_{1} \mathrm{R}$ and $\mathrm{YL}$.

Scotussa daguerrei (Mesa 1963a). - $\mathrm{X}_{1} \mathrm{R}$ and YL synapse partially despite YL being only moderately heteropycnotic. YR and $\mathrm{X}_{2}$ are euchromatic, but synapsis also seems to be partial along their distal halves. However, interstitial chiasmata are never formed. Asynapsis and nondisjunctional orientation are extremely rare.

Dichromatos lilloanus and D. schrottkyi (Castillo et al. 2010).- The genus, includes four species (Cigliano 2007), all showing the same sex-chromosome system of $\mathrm{X}_{1} \mathrm{X}_{2} \mathrm{Y}^{\lambda} / \mathrm{X}_{1} \mathrm{X}_{1} \mathrm{X}_{2} \mathrm{X}_{2}$. . The complex sexmechanism arose from a neo-XY system where a second centric fusion between the neo-Y and another autosome took place (Mesa 1962b, Castillo et al. 2010). Recently, D. lilloanus and D. schrottkyi were studied in detail (Fig. 2e, f); considering changes in the morphology, behavior and variations in chromatin condensation patterns between the XR and YL arms, a more recent origin was proposed of the neo-system of $D$. lilloanus than that of $D$. schrottkyi, suggesting an independent origin from a common neo-XY ancestral mechanism and karyotype. However, judging by the association patterns of the sex trivalent in male meiosis, both multiple sex chromosome systems may be advanced. Otherwise the association between the sex chromosomes' should be throughout the sex chromosomes length, with formation of chiasmata in the proximal and interstitial regions indicating homology and a recent origin, as in Leiotettix politus (Mesa \& Mesa 1967).

Regarding the frequency with which autosomes have become involved in centric fusions with the $\mathrm{X}$ or the neo- $\mathrm{Y}$ chromosome to produce neo-sex systems, we considered those species in which the participating autosomes could be identified by length (excluded were those cases where the exautosomes underwent extensive a posteriori changes that impeded their identification). It is usual to classify chromosomes of acridoid grasshoppers in three length groups: Large (L), Medium (M), and Small (S). A typical $2 \mathrm{n}=23 \hat{\jmath}$ / $24+$ karyotype usually consists of three large $\left(\mathrm{L}_{1}-\mathrm{L}_{3}\right)$, five medium $\left(\mathrm{M}_{4}-\mathrm{M}_{8}\right)$, and three small $\left(\mathrm{S}_{8}-\mathrm{S}_{11}\right)$. The $\mathrm{X}$ chromosome is usually included in the $\mathrm{M}$ group. However, the number of chromosomes falling into the different classes may vary in different species. The analysis of 51 neotropical species revealed that in 28 cases (55\%) of neo-sex systems, an L chromosome was involved, while 20 (39\%) and $3(6 \%)$ corresponded respectively to $\mathrm{M}$ and $\mathrm{S}$ chromosomes. A similar analysis in non-neotropical species revealed $22 \mathrm{~L}(63 \%)$, $12 \mathrm{M} \mathrm{(34 \% )}$ and $1 \mathrm{~S} \mathrm{(3 \% )} \mathrm{autosomal} \mathrm{involvement.} \mathrm{A} \mathrm{contingency}$ $\chi^{2}$ test did not show significant differences between both samples $\left(\chi^{2}=0.84 ; \mathrm{df}=2 ; p=0.66\right)$.

The former results suggest that centric fusions between sex-chromosomes and autosomes have been more successful the larger the autosomal partner is, even though spontaneous fusions in nature may occur at random between the $\mathrm{X}$ and any autosome. This makes sense on mechanical grounds: as stated above, centric fusions between very unequal partners are less likely to survive due to nondisjunctional segregation in meiosis of heterozygotes (males, in the case of neo-XY systems) that produces gametic imbalance (Bidau \& Mirol 1992). Reasonably proper meiotic segregation in males is essential for at least short-term survival of the newly arisen rearrangement. Extremely asymmetric X-autosome fusions are less likely to persist through successive meioses, and thus become fixed by chance in a population. The segregation problem also applies to heterozygous 

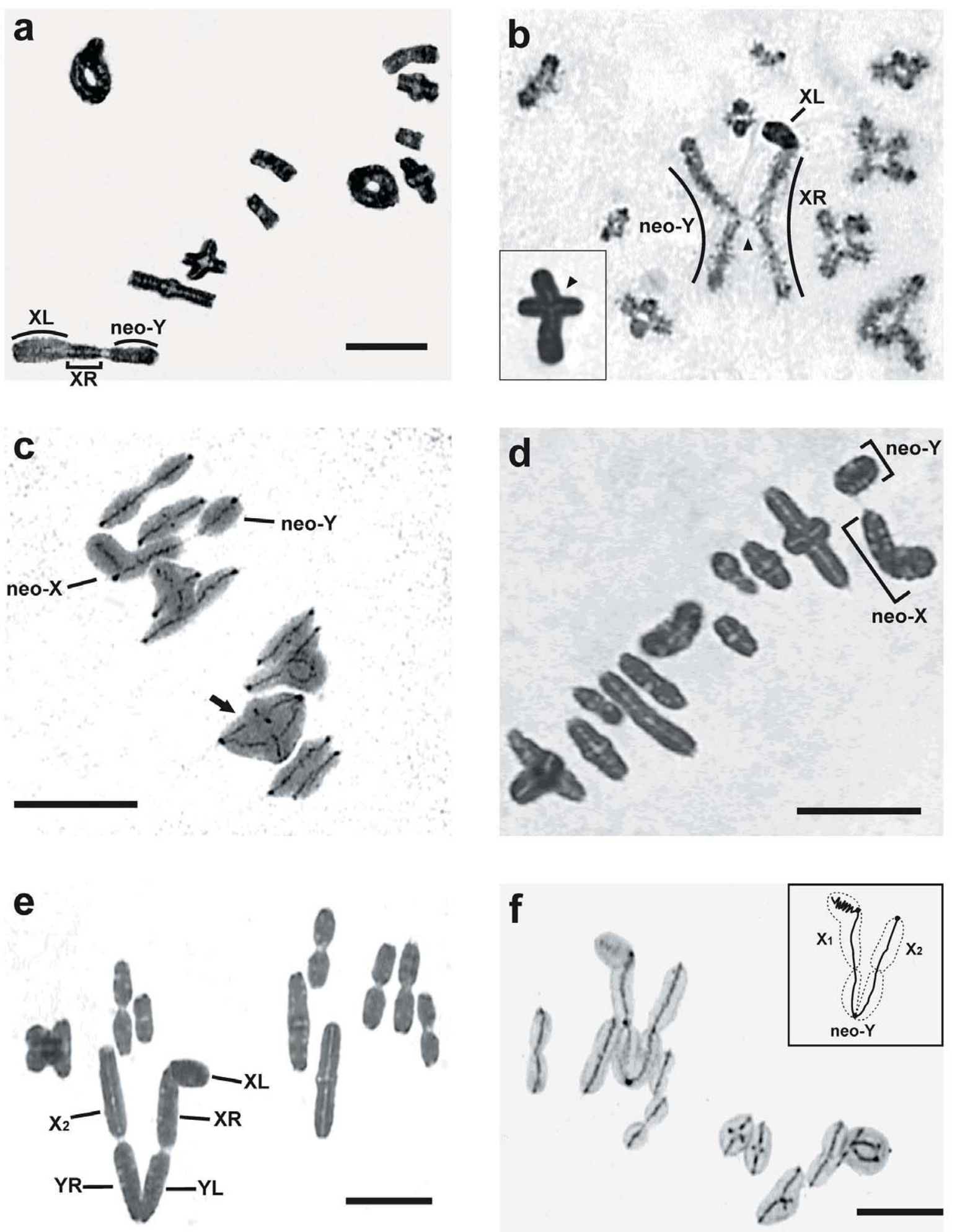

Fig. 2. Neo-sex chromosome systems of Neotropical Melanoplinae male meiosis. a) Pro-metaphase I of Baeacris punctulatus' spontaneous neo-XYmutant; the XL and XR arms and the neo-Y are indicated. Note the similar length and staining pattern of XR and neo-Y, both with an autosomal past (haematoxylin). b) Diplotene of Mariacris viridipes; XR, XL and neo-Y are indicated. Note interstitial chiasma (arrowhead) and the equal size and chromatin quality of XR and neo-Y, indicating a recent origin. Insert: the sex bivalent at metaphase I with interstitial chiasma (haematoxylin). c) Metaphase I of Ronderosia malloi; note the L-shaped orientation of the sex bivalent (silver impregnation). d) Metaphase I of Ronderosia bergi; the Neo-X and Neo-Y are indicated. Note the C-shaped orientation due to a pericentric inversion established in the neo-Y (haematoxylin). e) Metaphase I of Dichromatos schrottkyi, indicating the neo-sex chromosome arms (haematoxylin). f) Metaphase I of Dichromatos lilloanus; insert: schematic representation of neo- $\mathrm{X}_{1} \mathrm{X}_{2} \mathrm{Y}$ trivalent and its axial cores. Bar $=10 \mu \mathrm{m}$. 
females during the initial transient polymorphic stage after the new sex chromosomes start to spread. Some females will possess a normal $\mathrm{X}$ chromosome plus a neo-X and an unfused autosome, forming a meiotic trivalent that has to undergo disjunctional segregation lest fertility be impaired. Disjunctional segregation would also be facilitated if proximal chiasmata are impeded (Bidau \& Mirol 1992) and this may occur if previous distal localization occurs or if the fusion instantaneously abolishes proximal crossovers. This seems to be a usual property of centric fusions in grasshoppers and other animals (Martí \& Bidau 2001).

\section{Some final considerations on acridoid neo-sex chromosomes}

The high frequency of neo-sex systems in neotropical grasshoppers, as compared with acridomorph fauna from the rest of the world, is intriguing. Could this be related to a higher incidence of chromosomal rearrangements (e.g., centric fusions, the most frequent observed rearrangement) in neotropical taxa? And if this is so, what makes the difference?

In a review of cytogenetic data on South American Acridoidea, Mesa et al. (1982) examined this problem. In comparing frequencies of derived (rearranged) karyotypes and neo-sex systems between neotropical and rest-of-the-world Acridoidea, they found that frequencies of nonstandard $(2 n=22 \hat{O} / 23+)$ karyotypes were not significantly different between the two groups $(29.6 \%$ and $27.2 \%$, respectively) and that neo-sex chromosomes occurred in $17.6 \%$ and $3 \%$ of the species, respectively.

However, this comparison includes all Acridoidea families, which in fact, show great differences in frequencies of derived karyotypes and neo-sex systems and, within some genera, the observed rearrangements may not have been independent events but inherited from a common ancestral species, as in the Aleuasini where the original X-autosome fusion took place (see above).

The latter of course promotes a large bias in the comparison. For example: with a single exception, all studied neotropical Gomphocerinae have the standard Cryptosacci karyotype (Mesa et al. 1982 , this paper, Table 2). However, a large group of genera from the northern Hemisphere (formerly called truxaline grasshoppers), share a karyotype of $2 n=17 \hat{\delta} / 18$, with three fixed autosomal fusions. If the many species of these genera are included in the comparison, frequency of derived karyotypes would be inflated, since very probably the observed rearrangements occurred only once in a common ancestor.

However, as Mesa et al. (1982) indicate, the majority of derived karyotypes belong to the largest family, Acrididae, and within it, to the Melanoplinae ( 44 of 91 species, 48.4\%). Furthermore, melanoplines show the highest incidence of neo-sex chromosome systems. This high chromosomal variability is not reflected in melanoplines of the rest of the world, thus neo-XY and multiple mechanisms are more frequent in neotropical melanoplines. This is probably because of a greater karyotypic 'plasticity' or tendency to produce and/or fix novel chromosomal rearrangements.

Classic cytogenetic models of the occurrence of centric fusions in Orthoptera have been reviewed several times (John \& Hewitt 1968, White 1973, John \& Freeman 1975). For example, one obvious possibility is the simultaneous breakage in the pericentromeric regions of two acrocentrics, leading after reunion, to the production of a metacentric and the concomitant loss of a small chromosomal fragment. However, there are other possibilities, including both breaks occurring within the centromere in telocentrics (John \& Freeman 1976). Nevertheless no molecular models have been proposed for fusion propensity in grasshoppers, although they exist for other models. Since centric fusions in Orthoptera cause similar meiotic effects to those of for example, mammals (Bidau et al. 2001), analogous mechanisms could also promote centric fusions in grasshoppers and mammals.

Since centric fusions involve centric and pericentric regions of acro/telocentric chromosomes, it is logical to search for causes of rearrangement within the centromere and adjacent regions. Centromeres, associated kinetochores and DNA regions surrounding centromeres, are complex and rapidly evolving structures (Talbert et al. 2008). In the case of a classic example of Robertsonian variation, the house mouse (Mus domesticus), it was proposed that DNA-repeated sequences, or the organization of families of repeated sequences, influence the frequency of centric fusions (Redi et al. 1986, Redi \& Capanna 1988). In this model, centric fusion is the result of recombination between centromeric satellite DNA sequences shared by the different autosomes: if the enzyme machinery failed to separate a pair of replicating telomeres, then two chromosomes could be joined and one of the two kinetochore organizer sequences could be inactivated (Redi \& Capanna 1990).

However, the feasibility of such a model depends on the chances of centromeric homologous sequences meeting and interacting. In mice (and also in grasshoppers) it has been shown that one feature of the nuclear architecture of sex cells is that centromeres tend to cluster in vivo in a specific region of the nucleus (Redi \& Capanna 1990, Martí \& Bidau 2001). During discontinuous DNA synthesis of similar intermingled DNA sequences of nonhomologous chromosomes, unpaired single-strand regions (located at the telomericends next to centromeres), are able to occasionally base-pair. Incorrect repair would lead to the formation of a Robertsonian metacentric. Not only satellite DNA but transposable elements inserted in telomeric regions may promote interchange (Redi \& Capanna 1990).

Could a similar model be applicable to melanoplines? Perhaps, but at present there is no information on repeated sequences, transposable elements and centromere structure within this group and, least of all, no comparative studies between neotropical and rest-ofthe-world Melanoplinae. Nevertheless, despite the possibility that centric fusions could occur more frequently in neotropical species, there is the problem of fixation of A-A and X-A fusions. It could well be that frequency of spontaneous occurrence of both types of fusions is not different between both groups of melanoplines, but that the chance of fixation is. A number of classic chromosomal speciation models are based on the fact that newly arisen chromosomal mutations (i.e., centric fusions) can only become fixed by drift in a very small population, especially if its effects are detrimental in heterozygotes (White 1978, Rieseberg 2001). But other mechanisms can increase the chances of fixation.

The disproportionate neotropical frequency of Rb karyotypes may be due to centromere drive. This theory (Pardo-Manuel de Villena \& Sapienza 2001), proposes that the establishment of Robertsonian or alternatively, acro/telocentric chromosomes within an evolutionary lineage, is due to a bias of female meiosis favoring either less or more centromeres passing to the oocyte nucleus, respectively. This nonMendelian transmission would result from a basic asymmetry of the female meiotic spindle; thus when heterozygous Rb configurations are present, the partner bearing fewer centromeres will attach more frequently to the spindle pole that is less efficient in capturing centromeres, favoring metacentric chromosome transmission.

The direction of drive may change frequently over evolutionary time (Pardo-Manuel de Villena \& Sapienza 2001). Grasshopper female spindles are extremely asymmetric (Hewitt 1976, 1979), and recently Bidau and Martí (2004) obtained indirect evidence of the operation of centromere drive for metacentric chromosomes in Dichroplus pratensis. Selection to reduce the burden of B chromosomes 
(usually acrocentric) could be a factor directly involved in reverting the spindle egg's polarity towards capturing fewer centromeres, thus boosting metacentric transmission (Bidau \& Martí 2004, Palestisetal. 2004, Malik 2009, Talbert et al. 2008). Conversely, selection towards more inter- and intrachromosomal recombination in marginal populations, which facilitates adaptation to harsh environments, would favor acrocentric drive (Bidau \& Marti 2002).

In fact, both phenomena occur in mammals: in humans the Robertsonian fusions are preferentially transmitted through female meiosis, but in mice, acrocentrics are preferred (Malik 2009). Thus, lineages that tend to fix neo-XY systems (and autosomal fusions) would predictably have lower incidences of B-chromosomes. It is then possible that the tendency for fixation of centric fusions in neotropical Melanoplinae is an inherent property of metacentric $\mathrm{Rb}$ chromosomes, including the neo-sex chromosomes, to migrate to the oocyte pole preferentially due to spindle asymmetry (Castillo et al. 2010).

In summary, neotropical high karyotypic diversity would be a consequence of an ancient South American melanopline origin (Amédégnato et al. 2003), and drive mechanisms which could have been inverted during expansion out of South America, favoring acrocentric karyotypes.

The process of progressive degeneration of the Y chromosome poses some very intriguing problems (Turner 2005). As we have seen, there are large groups of insects (and other invertebrates, like the Nematoda) in which the vast majority of species lacks a Y chromosome. However, it is always assumed that the ancestors of these taxa had typical XY/XX sex-chromosome systems (White 1960, Charlesworth 1999). This has been documented in Caenorhabditis elegans (Larsson \& Meller 2006). Thus, it seems that degeneration of the $\mathrm{Y}$ is an inexorable process that eventually leads to its loss. However, the persistence of the $\mathrm{Y}$ chromosome in most groups suggests they can arise de novo (Veltsos et al. 2008). Furthermore, neo-XY systems indicate that this is what actually happens in the Orthoptera and many other taxa.

This situation implies a further problem: how can the new $\mathrm{Y}$ chromosome that arose as a spontaneous mutant in a single individual become fixed in a population and subsequently spread throughout the range of the species? Problems arise in the first place because male (and female) carriers of the sexual rearrangement are structural heterozygotes and these may have reduced fertility due to meiotic segregation difficulties or altered recombination patterns, thus requiring for example, chance fixation in a small population (drift) or some selective advantage that over-rides the negatively heterotic effects. However, this does not explain further spread throughout the species range, because the new form will be in the minority when meeting the ancestral form.

Veltsos et al. (2008) have modeled this problem using the alpine grasshopper Podisma pedestris which has a standard $\mathrm{XO} / \mathrm{XX}$ race and a neo-XY/neo-XX race, which form a hybrid zone in the southern Alps (Hewitt 1975). The authors found that sexually antagonistic effects of the neo-Y induce indirect selection in favor of the fused $\mathrm{X}$-chromosomes. This results in their spread in the hybrid zone. The neo-Y thus can spread because it is protected behind the advancing shield of the neo-X distribution, despite having mutations (accumulated because of restrictions on recombination with the neo-X) that could cause it to be selected against. It seems paradoxical that its degeneration can be the factor that favors its spread.

It is also puzzling why neo-Y species of Orthoptera do not revert to an XO state by erosion of the neo-Y chromosome. As discussed above, evolutionary recent neo-XY systems are characterized by full pachytene synapsis of $\mathrm{Y}$ and $\mathrm{XR}$, interstitial chiasma formation and lack of heterocromatinization of the Y (i.e., Podisma pedestris,
Baeacris punctulatus, Leiotettix sanguineus), while advanced or 'old' systems show restriction of synapsis and recombination between both elements, which only maintain a distal-terminal association for meiotic segregation. In these cases, the neo-Y is usually almost completely heterochromatic and sometimes, rearranged (a sign of degeneration) (i.e., Ronderosia bergi) and in some cases the XR arm has also became heterochromatinized (i.e., Aleuas, Zygoclistron). In extreme cases, even XL may be involved in an internal chromosomal rearrangement (i.e., Dichroplus vittatus). Intermediate cases show a mixture of both classes of systems (i.e., Xyleus laevipes).

It is puzzling, however, that not a single instance of complete loss of the neo-Y has been observed in Orthoptera, which would be expected as the final stage of $\mathrm{Y}$ degeneration. Loss of the $\mathrm{Y}$ from a former neo-XY system would not be difficult to detect, owing to the especial characteristics of the neo-X chromosome. Furthermore, in acridids neo-XY systems have repeatedly and independently evolved towards a more complex system.

What can be said about orthopteran neo-sex chromosome function is essentially speculative, mainly because almost nothing is known about the genetic and developmental basis of sex determination in Orthoptera. The ancient loss of the putative primitive Y chromosome in the whole group, presumably indicates that whatever sex-determining genes existed in the primitive $\mathrm{Y}$, must have been transferred to the autosomes. Furthermore, there are some indications that, as in Drosophila, sex in Orthoptera might be determined by the ratio of the number of $\mathrm{X}$ chromosomes to haploid sets of autosomes (X/A ratio) and that dosage compensation in the few species studied is of the Drosophila type, with a single exception (Rao \& Padmaja 1992).

According to Charlesworth (2001) this type of system must be secondarily evolved from a male Y-determining system. However, in these cases the $\mathrm{Y}$ chromosome either remains as a genetic entity or could be lost entirely, as in Orthoptera (Kejnovsky et al. 2009). Then, why do neo-sex systems appear and persist in grasshoppers and then undergo degeneration, as other Y chromosomes? One possibility is that the $\mathrm{X}$-autosome fusion produces favorable new linkage relationships between genes in the $\mathrm{X}$ and the autosome, some of which could be sex-determination-related, creating a new balance between sex chromosomes and autosomes. The neo-Y would then follow the inexorable path of the Y chromosome, as indicated before. It is also possible that some important autosomal genes that must persist in double dose in both sexes, impede neo-Ý elimination, despite degeneration, or else that during its evolution the neo-Y acquired other autosomal segments (Graves 2005), for example by retrotransposition (Lahn \& Page 1999).

The former considerations could have connection with the hypothesis of Mesa et al. (2001), that acquisition of a neo-sex system condemns species of grasshoppers to a short evolutionary career, that is, to extinction. The authors based their hypothesis on the observed fact that no major taxon (tribe, family) of acridids shows neo-sex chromosomal mechanisms throughout all their species.

However, there are a few well-studied genera in which all studied species share very similar neo-XY systems: these could have derived from a common ancestor in which the original X-autosome fusion occurred. Examples of the latter among neotropical Melanoplinae are the closely related Aleuas and Zygoclistron (in which eight studied species may have inherited their very similar neo-XY chromosomes from a common ancestor), Ronderosia, Dichromatos and Leiotettix. Other cases may be represented by Paratylotropydia, Mermiria and Hesperotettix from the northern hemisphere (however, these genera were studied in the early days of cytogenetics and clear comparisons among species are difficult, owing to the techniques and illustrations then used). It is true that in many instances only one species 
Fig. 3. Four melanopline species with neo-sex chromosomes studied by the authors. a) $D i$ chromatos schrottkyi male, Yaguarundí, Misiones, Argentina. b) Ronderosia bergi male. Lesser, Salta, Argentina. c) Ronderosia forcipatus female, Antequera, Chaco, Argentina. d) Dichroplus maculipennis female, Laprida, Buenos Aires, Argentina. For color version, see Plate I.
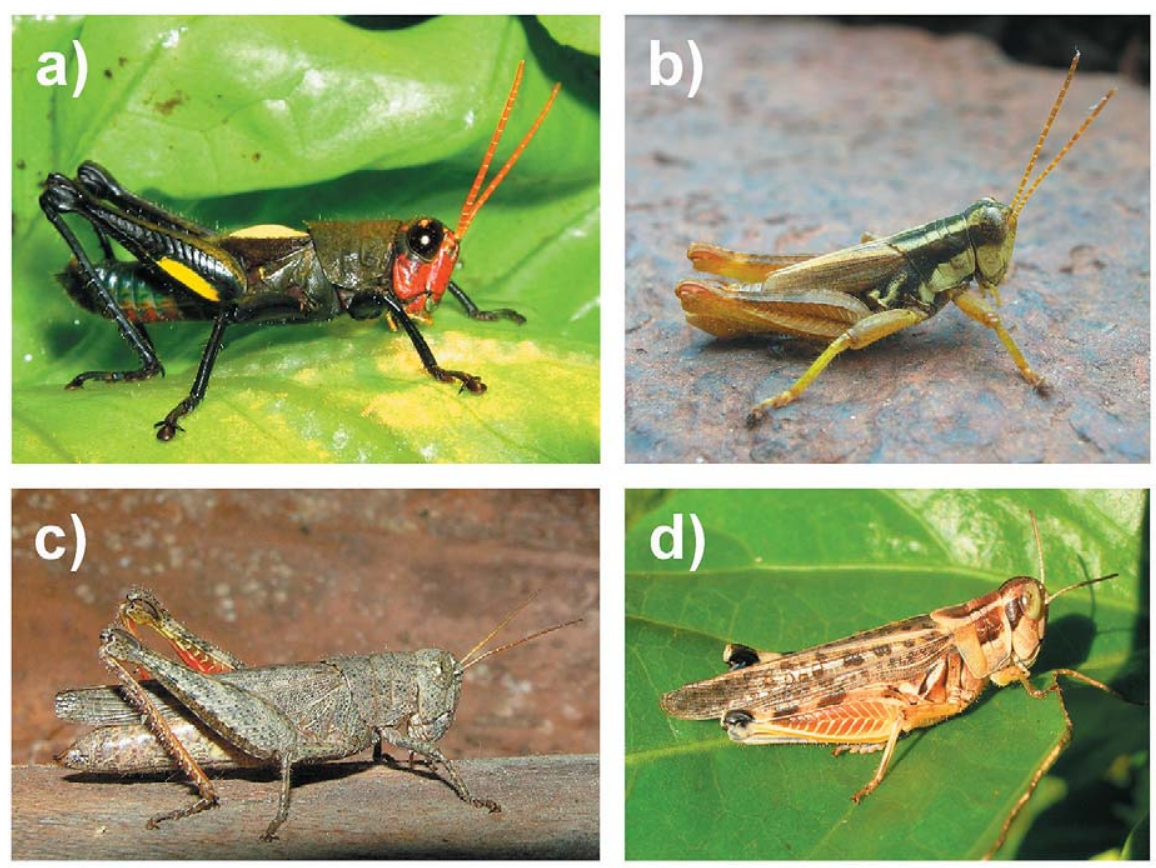

within a genus exhibits derived sex chromosomes or, as in the case of the neotropical melanopline Dichroplus or the Australian Tolgadia (Oxyinae), all known cases of derived systems seem to have arisen from independent rearrangement events.

Nevertheless, it is highly speculative to assign neo-sex chromosomes a role in precluding further speciation leading to eventual extinction. So little is known about the role of neo-Y chromosomes in Acrididae it is premature to reach such a conclusion and new studies with modern techniques are needed to understand chromosomal sex determination in the Orthoptera, which could help explain the role of new chromosomal sex systems in grasshoppers. A promising approach however, has recently been reviewed by Verhulst et al. (2010). In all studied insects including dipterans, coleopterans, lepidopterans and hymenopterans, a conserved switch gene, doublesex $(d s x)$ that controls sexual differentiation, is the end of a cascade of genes that processes the primary signal that starts sex differentiation. Another ancestral gene, transformer (tra), is the $d s x$ splicing regulator, but despite its conserved function it shows considerable sequence variability, indicating that in different groups it can process a variety of upstream sex-determining signals. The latter is reasonable considering the multitude of mechanisms of sexual determination of insects. No studies in Orthoptera, which probably rely on sex-chromosome dose as a primary signal, have been made to date. Research in this direction will probably shed much light on sex determination and sex-chromosome evolution in grasshoppers.

\section{Acknowledgements}

We are grateful to María Marta Cigliano, Glenn Morris and the Orthopterists' Society for the opportunity to write this review in honor of Michael J. D. White.

\section{References}

Amédégnato C., Chapco W., Litzenberger G. 2003. Out of South America? Additional evidence for a southern origin of melanopline grasshoppers. Molecular Phylogenetics and Evolution 28: 115-119.

Ashley T. 2002. X-autosome translocations, meiotic synapsis, chromosome evolution and speciation. Cytogenetic and Genome Research 96: 3339.
Ault J.G. 1996. Contributions of insect systems to the chromosome theory of inheritance and to our understanding of chromosome behaviour on the spindle. International Journal of Insect Morphology and Embryology 25: 93-114.

Bachtrog D., Charlesworth B. 2002. Reduced adaptation of a nonrecombining neo-Y chromosome. Nature 416: 323-326.

BaumgartnerW.J. 1904. Evidences for the individuality of the chromosomes. Biological Bulletin 8: 1-28.

Bateson W., Saunders E.R. 1902. Experiments in the physiology of heredity. Reports to the Evolution Committee of the Royal Society 1: 1-160.

Bidau C.J. 1990. The complex Robertsonian system of Dichroplus pratensis (Melanoplinae, Acrididae). II. Effects of the fusion polymorphisms on chiasma frequency and distribution. Heredity 64: 145-159.

Bidau C.J., Giménez M.D., Palmer C.L., Searle J.B. 2001. The effects of Robertsonian fusions on chiasma frequency and distribution in the house mouse (Mus musculus domesticus) from a hybrid zone in northern Scotland. Heredity 87: 305-313.

Bidau C.J., Martí D.A. 2001. Meiosis and the Neo-XY of Dichroplus vittatus (Melanoplinae, Acrididae): a comparison between sexes. Genetica 110: 185-194.

Bidau C.J., Martí D.A. 2002. Geographic distribution of Robertsonian fusions in Dichroplus pratensis (Melanoplinae, Acrididae): the central-marginal hypothesis reanalysed. Cytogenetic and Genome Research 96: 66-74.

Bidau C.J., Martí D.A. 2004. B chromosomes and Robertsonian fusions of Dichroplus pratensis (Acrididae): intraspecific support for the centromeric drive theory. Cytogenetic and Genome Research 106: 347-350.

Bidau C.J., Martí D.A. 2010. 110 years of orthopteran cytogenetics, the chromosomal evolutionary viewpoint, and Michael White's signal contributions to the field. Journal of Orthoptera Research, this issue.

Blakeslee A.F. 1907. The biological significance and control of sex. The nature and significance of sexual differentiation in plants. Science 25: 366-372.

Bone J.R., Kuroda M. 1996 Dosage compensation regulatory proteins and the evolution of sex chromosomes in Drosophila. Genetics 144: 705-713.

Bressa M.J., Papeschi A.G. Vítková M., Kubíčková S., Fuková I., Pigozzi M.I., Marec F. 2009. Sex chromosome evolution in cotton stainers of the genus Dysdercus (Heteroptera: Pyrrhocoridae). Cytogenetic and Genome Research 125: 292-305.

Bugrov A. 1986. Neo-XY sex chromosome determination in the grasshopper Asiotmethis heptapotamicus heptapotamicus (Zub.) and Atrichotmethis semenovi (Zub.). (Orthoptera, Pamphagidae). Tsitologia 28: 117-119 (in Russian). 
Bugrov A., Gozeva S. 1998. Neo-XY chromosome sex determination in four species of the Pamphagidae grasshoppers (Orthoptera, Acridoidea, Pamphagidae) from Bulgaria. Caryologia 51: 115-121.

Bugrov A.G., Warchalowska-Śliwa E. 1997. Chromosome numbers and C-banding patterns in some Pamphagidae grasshoppers (Orthoptera, Acridoidea) from the Caucasus, Central Asia, and Transbikalia. Folia Biologica 45: 133-138.

Camacho J.P.M., Sharbel T.F., Beukeboom L.W. 2000. B-chromosome evolution. Philosophical Transactions Royal Society of London B 355: 163-178.

Carbonell C.S., Mesa A. 2006. Ronderosia ommexechoides: a new species of Brazilian Dichroplini (Orthoptera: Acrididae, Melanoplinae). Neotropical Entomology 35: 632-637.

Cardoso H., Dutra A. 1979. The neo-X neo-Y sex pair in Acrididae, its structure and association. Chromosoma 70: 323-336.

Cardoso H., Sáez F.A., Brum-Zorrilla N. 1974. Location, structure and behaviour ofC-heterochromatin during meiosis in Dichroplus silveiraguidoi (Acrididae-Orthoptera). Chromosoma 48: 51-64.

Castillo E.R.D., Bidau C.J., Martí D.A. 2010. Neo-sex chromosome diversity in neotropical melanopline grasshoppers (Melanoplinae, Acrididae). Genetica 138: 775-786.

CastleWE. 1903. The heredity of sex. Bulletin of the Museum of Comparative Zoology 40: 190-218.

Charlesworth B. 1991. The evolution of sex chromosomes. Science 251: 1030-1033.

Charlesworth B. 1996. The evolution of chromosomal sex determination and dosage compensation. Current Biology 6: 149-152.

Charlesworth B. 2002. The evolution of chromosomal sex determination, pp. 207-219. In: Chadwick D., Goode J. (Eds) The Genetics and Biology of Sex Determination. Novartis Foundation Symposium 244. Volume 244, Novartis Foundation, London.

Charlesworth B. 2004. Sex determination: primitive Y chromosomes in fish. Current Biology 14: 745-747.

Charlesworth B., Charlesworth D. 2000. The degeneration of Y chromosomes. Philosophical Transactions Royal Society of London B Biological Sciences 355: 1563-1572.

Charlesworth D., Charlesworth B., Marais G. 2005. Steps in the evolution of heteromorphic sex chromosomes. Heredity 95: 118-128.

Cigliano M.M. 2007. Review of the South American genus Eurotettix Bruner (Orthoptera, Acridoidea, Melanoplinae). Systematic Entomology 32: 176-195.

Conklin E.G. 1913. Professor Thomas Harrison Montgomery, Jr. Science 39: 207-214.

Cooper K.W. 1946. The mechanism of non-random segregation of sex chromosomes in male Drosophila miranda. Genetics 31: 181-194.

Darlington C.D. 1958. Evolution of Genetic Systems. Oliver \& Boyd, London.

Deakin J.E., Hore T.A., Koina E., Graves J.A.M. 2008. The status of dosage compensation in the multiple $\mathrm{X}$ chromosomes of the platypus. PLoS Genetics 4: e1000140.

del Cerro A.L., Cunãdo N., Santos J.L. 1998. Synaptonemal complex analysis of the X1X2Y trivalent in Mantis religios $a$ L. males: inferences on the origin and maintenance of the sex-determining mechanism. Chromosome Research 6: 5-11.

Delgado Echeverría I. 2000. Nettie Maria Stevens y la Función de los Cromosomas Sexuales. Seminario Interdisciplinar de Estudios de las Mujeres de la Universidad de Zaragoza, Spain.

Díaz M.O., Sáez F.A. 1968. DNA synthesis in the neo-X neo-Y sex determination system of Dichroplus bergi (Orthoptera: Acrididae). Chromosoma 24: 10-16.

Ferguson-Smith M. 2007. The evolution of sex chromosomes and sex determination in vertebrates and the key role of DMRT1. Sexual Development 1: 2-11.

Ferreira A. 1969. Chromosome survey of some Australian tettigoniids (Orthoptera - Tettigonioidea): two species with neo-XY sex determining mechanism. Cytologia 34: 511-522.
Ferreira A. 1975. Estudo citológico em acridoideos brasileiros. Aleuas gracilis, uma espécie com uma sistema de determinação sexual de tipo neo XY altamente evoluído. Ciéncia e Cultura 27: 326-332.

Ferreira A. 1976. Cytology of Brazilian Phaneropteridae (OrthopteraTettigonioidea): a species with neo XY sex determining mechanism. Canadian Journal of Genetics and Cytology 18: 79-84.

Ferreira A., Mesa A. 1979. Neo-XY sex chromosomes in Zygoclistrum nasicum (Orthoptera-Acridoidea). Caryologia 42: 53-59.

Ferreira A., Mesa A., Carbonell C.S. 1980. The chromosomes of neotropical short-horned grasshoppers of the tribe Abracrini (Orthoptera, Acridoidea, Acrididae, Omamtolampinae). Naturalia 5: 89-95.

Ferreira A., Mesa A. 2010. Cytotaxonomy of the genus Dichromatos Cigliano 2007 (Orthoptera, Acridoidea, Melanoplinae) Journal of Orthoptera Research 19: 233-237.

Goldschmidt E. 1949. Multiple sex-chromosome mechanisms and polyploidy in animals. Journal of Genetics 50: 434-440.

Goldschmidt R. 1923. The Mechanism and Physiology of Sex Determination. Methuen, London.

Graves J.A.M. 2002. Sex chromosomes and sex determination in weird animals. Cytogenetics and Genome Research 96: 161-168.

Graves J.A.M. 2005. Recycling the Y chromosome. Science 307: 50-51.

Gruetzner F., Ashley T., Rowell D.M., Graves J.A.M. 2006. How did the platypus get its sex chromosome chain? A comparison of meiotic multiples and sex chromosomes in plants and animals. Chromosoma 115: 75-88.

Harper R.A. 1907. Sex-determining factors in plants. Science 25: 379382.

Helwig E.W. 1941. Multiplechromosomes in Philocleon anomalus (Orthoptera: Acrididae). Journal of Morphology 69: 317-327.

Helwig E.W. 1942. Unusual integrations of the chromatin in Machaerocera and other genera of the Acrididae (Orthoptera). Journal of Morphology 71: 1-33.

Henking H. 1891. Erste Entwickelungsvorgänge in den Eiern der Insecten. Zeitschrift für Wissenschaften Zoölogie 51: 685-736.

Hewitt G.M. 1975. A sex chromosome hybrid zone in the grasshopper Podisma pedestris (Orthoptera: Acrididae). Heredity 35: 375-387.

Hewitt G.M. 1976. Meiotic drive for B-chromosomes in the primary oocytes of Myrmeleotettix maculatus (Orthoptera: Acrididae). Chromosoma 56: 381-391.

Hewitt G.M. 1979. Animal Cytogenetics, vol. 3, Insecta 1. Orthoptera. Grasshoppers and crickets. Gebrüder Borntraeger, Berlin.

Hobza R., Lengerova M., Cernohorska H., Rubes J., Vyskot B. 2004. FAST-FISH with laser beam microdissected DOP-PCR probe distinguishes the sex chromosomes of Silene latifolia. Chromosome Research 12: 245-250.

Hobza R., Kejnovsky E., Vyskot B., Widmer A. 2007. The role of chromosomal rearrangements in the evolution of Silene latifolia sex chromosomes. Molecular Genetics and Genomics 278: 633-638.

Hobza R., Lengerova M., Svoboda J., Kubekova H., Kejnovsky E., Vyskot B. 2006. An accumulation of tandem DNA repeats on the Y chromosome in Silene latifolia during early stages of sex chromosome evolution. Chromosoma 115: 376-382.

Hoffmann A.A., Rieseberg L.H. 2008. From population genetic markers to drivers of adaptive shifts and speciation? Annual Review of Ecology, Evolution and Systematics 39: 21-42.

Hughes-SchraderS. 1947. Reversion of XO toXY sexchromosome mechanism in a phasmid. Chromosoma 3: 57-65.

John B. 1983. Therole of chromosome change in theevolution of orthopteroid insects, pp. 1-110. In: Sharma A.K., Sharma A.S. (Eds) Chromosomes in the Evolution of Eukaryotes, CRC Press, Boca Ratón,

John B., Freeman M. 1975. Causes and consequences of Robertsonian exchange. Chromosoma 52: 123-126.

John B., Hewitt G.M. 1966. Karyotype stability and DNA variability in the Acrididae. Chromosoma 20: 155-172.

John B., Hewitt G.M. 1968. Patterns and pathways of chromosomeevolution within the Orthoptera. Chromosoma 25: 40-74.

John B., King M. 1977. Heterochromatin variation in Cryptobothrus chrysophorus. I. Chromosome differentiation in natural populations. Chromosoma 64: 219-239. 
John B., Lewis K.R. 1965. The Meiotic System. Protoplasmatologia 6 (F1). Springer-Verlag, Berlin.

Just W., Baumstark A., Hameister H., Schreiner B., Reisert I., Hakhverdyan M., Vogel W. 2002. The sex determination in Ellobius lutescens remains bizarre. Cytogenetics and Genome Research 96: 146-153.

Kaiser V.B., Bachtrog D. 2010. Evolution of sex chromosomes in insects. Annual Review of Genetics 44: 91-112.

Kejnovsky E., Hobza R., Cermak T., Kubat Z., Vyskot B. 2009. The role of repetitive DNA in structure and evolution of sex chromosomes in plants. Heredity 102: 533-541.

Kingsland S.E. 2007. Mantaining continuity through a scientific revolution. A rereading of E. B. Wilson and T. H. Morgan on sex determination and Mendelism. Isis 98: 468-488.

Kitano J., Ross J.A., Mori S., Kume M., Jones F.C., Chan Y.F., Absher D.M., Grimwood J., Schmutz J., Myers R.M., Kingsley D.M., Peichel C.L. 2008. A role for a neo-sex chromosome in stickleback speciation. Nature 461: 1079-1083.

Kowalczyk M., Tatsuta H., Grzywacz B., Warchałowska-Śliwa E. 2008. Relationship between chromosomal races/subraces in the brachypterous grasshopper Podisma sapporensis (Orthoptera: Acrididae) inferred from mitochondrial ND2 and COI gene sequences. Annals of the Entomological Society of America 101: 837-844.

Lafuente N. 1977. Citogenética del género Dichroplus. Anales del Museo de Historia Natural de Valparaíso 10: 211-214.

Lafuente N., Esponda P., Solerviscens J. 1968. Citotaxonomía en ortópteros chilenos. Revista Chilena de Entomología 6: 91-99.

Lahn B.T., Page D.C. 1999. Four evolutionary strata on the human X chromosome. Science 286: 964-967.

Larsson J., Meller V. 2006. Dosage compensation, the origin and the afterlife of sex chromosomes. Chromosome Research 14: 417-431.

Li X.J., Zhang D.C., Wang W.Q. 2005. Chromosomal C-banding karyotype of 2 species of genus Asiotmethis (Acridoidea: Pamphagidae) from China. Yi Chuan 27: 735-749.

Lillie F.R. 1907. The biological significance of sexual differentiation-a zoological point of view. Science 25: 372-376.

Mahesh G., Ramachandra N.B., Ranganath H.A. 2001. Autoradiographic study of transcription and dosage compensation in the sex and neosex chromosomes of Drosophila nasuta nasuta and Drosophila nasuta albomicans. Genome 44: 71-78.

Malik H. 2009. The centromere-drive hypothesis: a simple basis for centromere complexity, pp. 33-52. In: Ugarković D. (Ed.), Centromere, Progress in Molecular and Subcellular Biology 48. Springer-Verlag Berlin Heidelburg.

Marin I., Siegal M.L., Baker B.S. 2000. The evolution of dosage-compensation mechanisms. Bioessays 22: 1106-1114.

Martí D.A., Bidau C.J. 2001. Synapsis in Robertsonian heterozygotes and homozygotes of Dichroplus pratensis (Melanoplinae, Acrididae) and its relationship with chiasma patterns. Hereditas 134: 245-254.

Martins L.A.-C.P. 1999. McClung and gender determination: from wrong to right. História, Ciências, Saúde-Manguinhos 6: 235-256.

McClung C.E.1899. A peculiar nuclear element in the male reproductive cells of insects. Zoological Bulletin 2: 187-197.

McClung C.E. 1900. The spermatocyte divisions of the Acrididae. Kansas University Quarterly 9: 73-100.

McClung C.E.1901. Notes on the accessory chromosome. Anatomischer Anzeiger 20: 220-226.

McClung C.E. 1902. The accessory chromosome-sex determinant? Biological Bulletin 3: 43-84.

McClung C.E.1905. The chromosome complex of orthopteran spermatocytes. Biological Bulletin 9: 304-340.

McClung C.E. 1917. The multiple chromosomes of Hesperotettix and Mermiria. Journal of Morphology 29: 519-605.

Mesa A. 1956. Los cromosomas de algunos acridoideos uruguayos (Orth., Caelif., Acridoidea). Agros 141: 32-45.

Mesa A. 1961. Morfología fálica y cariología de Neuquenina fictor (Rehn) (Orthoptera-Acridoidea). Comunicaciones Zoológicas del Museo de Historia Natural de Montevideo 5: 1-11.
Mesa A. 1962a. Los cromosomas de Eurotettix lilloanus Lieb. (Orthoptera, Catantopidae). Acta Zoológica Lilloana 18: 99-104.

Mesa A. 1962b. Cariología de Dichroplus bergi Stål (Orthoptera, Acrididae). Revista de Agricultura de Piracicaba 37: 41-49.

Mesa A. 1963a. Mecanismo cromosómico de determinación poco frecuente en Scotussa daguerrei Lieb. (Orthoptera-Acdididae). Revista de la Sociedad Entomológica Argentina 26: 119-124.

Mesa A. 1963b. Acerca de la cariología de Ommexechidae (OrthopteraAcridoidea). Revista de la Sociedad Uruguaya de Entomología 5: 3743.

Mesa A. 1964a. Cariología de Scotussa delicatula Lieb. (Orthoptera, Acrididae). Annals II Congresso de Zoologia de São Paulo 1: 3-7.

Mesa A. 1964b. Los cromosomas de Pachyossa sp. (Orthoptera, Ommexechidae). Revista de la Sociedad Uruguaya de Entomología 6: 49-54.

Mesa A. 1971a. Cariología de tres species de acridios del género Dichroplus (Orthoptera, Acrididae). Revista Peruana de Entomología 14: 233237.

Mesa A. 1971b. Estudios cromosómicos en dos especies andinas de acridios (Orthoptera-Acrididae). Revista Peruana de Entomología 14: 225-228.

Mesa A. 1973a. Mecanismo cromosómico de determinación sexual poco frecuente en Scotussa daguerrei Lieb. (Orthoptera, Acrididae). Revista de la Sociedad Entomológica Argentina 26: 119-124.

Mesa A. 1973b. Los cromosomas de algunos acridoideos chilenos (Orthoptera). Trabajos del V Congreso Latinoamericano de Zoologia, Montevideo 1: 150-161.

Mesa A., Ferreira A. 1977. Cytological studies in the family Ommexechidae (Orthoptera-Acridoidea). Acrida 6: 261-271.

Mesa A., Ferreira A. 1978. The chromosomes of South American Eumastacids (Orthoptera: Eumastacidae) and discussion of the phylogeny of the family. Acrida 7: 157-163.

Mesa A., Ferreira A. 1981. Have the Australian Morabinae and the neotropical Proscopiidae evolved from a common ancestor? A cytogenetic point of view (Orthoptera, Caelifera, Eumastacoidea). Acrida 10: 205-217.

Mesa A., Ferreira A., Carbonell C.S. 1982. Cariología de los acridoideos neotropicales: estado actual de su conocimiento y nuevas contribuciones. Annales de la Societé Entomologique de France (N.S.) 18: 507-526.

Mesa A., Ferreira A., Mesa R.S. de. 1969. The chromosomes of three Australian species of Gryllacridids (Gryllacridoidea-RaphidiophoridaeMacropathinae). Caryologia 22: 149-160.

Mesa A., Fontanetti C.S., Costa H. 1990. The karyotype of the grasshopper Spathalium helios (Orthoptera, Acridoidea,Ommexechidae). Revista Brasileira de Genética 13: 705-710.

Mesa A., Fontanetti C.S., García Novo P. 2001. Does an X-autosome centric fusión in Acrdoidea condemn the species to extinction? Journal of Orthoptera Research 10: 141-146.

Mesa A., Fontanetti C.S., Ferreira A. 2010. Karyotype and neo-sex chromosomes of Scaphura nigra (Orthoptera, Ensifera, Tettigoniidae, Phaneropterinae). Journal of Orthoptera Research, this issue.

Mesa A., García-Novo P. 2001. Neometrypus badius a new species of cricket with an unusual sex determining mechanism (Grylloidea, Eneopteridae, Tafaliscinae, Neometrypini). Journal of Orthoptera Research 10: 8187.

Mesa A., Mesa R.S. de. 1967. Complex sex-determining mechanisms in three species of South American grasshoppers (Orthoptera, Acridoidea). Chromosoma 21: 163-180.

Mesa A., Mesa R.S. de. 1971. Citología y evolución de Macropathinae (Orthoptera-Gryllacridoidea-Raphidiophoridae). Revista Peruana de Entomología 14: 220-224.

Mirol P.M., Bidau C.J. 1992. Proximal chiasmata induce non-disjunctional orientation of Robertsonian trivalents in a grasshopper. Heredity 69: 268-278.

Montgomery T.H., Jr.1898. The spermatogenesis in Pentatoma up to the formation of the spermatid. Zoologische Jahrbücher 12: 1-88.

Montgomery T.H. Jr. 1901 A study of the chromosomes of the germ cells of the Metazoa. Transactions American Philosophical Society 20: 154-236. 
Montgomery T.H. Jr. 1910. Are particular chromosomes sex determinants? Biological Bulletin 19: 1-17.

Moore R.C. 2009. Sex chromosomeevolution: a'missing link' in the evolution of sex chromosomes. Heredity 102: 211-212.

Morgan T.H. 1903. Recent theories in regard to the determination of sex. Popular Science Monthly 64: 97-116

Morgan T.H. 1907. Sex determining factors in animals. Science 25: 382384.

Morgan T.H. 1909. A biological and cytological study of sex determination in phylloxerans and aphids. Journal of Experimental Zoology 7: 239351

Morgan T.H., Sturtevant A.H., Muller H.J., Bridges C.B. 1915. The Mechanism of Mendelian Heredity. H. Holt \& Co., New York.

Nicolas M., Marais G., Hykelova V., Janousek B., Laporte V., Vyskot B., Mouchiroud D., Negrutiu I., Charlesworth D., Moneger F. 2005. Agradual process of recombination restriction in the evolutionary history of the sex chromosomes in dioecious plants. PLoS Biology 3: 47-56.

Ohno S. 1967. Sex Chromosomes and Sex Linked Genes. Springer, Berlin, Heidelberg, New York.

Palestis B.G., Burt A., Jones R.N., Trivers R., 2004. B chromosomes are more frequent in mammals with acrocentric karyotypes: support for the theory of centromeric drive. Proceedings Royal Society of London B Supplement 271: S22-S24.

Pannell J.R., Pujol B. 2009. The paradoxical spread of a new Y chromosome-a novel explanation. Trends in Ecology and Evolution 24: 59-63.

Pardo-Manuel de Villena F., Sapienza C. 2001. Female meiosis drives karyotypic evolution in mammals. Genetics 159: 1179-1189.

Piza S. de Toledo Jr 1951. Um par de autossomios heteromorfos no gafanhoto sul-americano Zoniopoda iheringi Pict. \& Sauss. Scientia Genética 4: 73-78.

Rao S.R.V., Padmaja M. 1992. Mammalian-type sex dosage compensation mechanism in an insect Gryllotalpa fossor (Scudder) Orthoptera. Journal of Biosciences 17: 253-273.

Redi C.A., Capanna E. 1988. Robertsonian heterozygotes in the house mouse and the fate of their germ cells, pp. 315-359. In: Daniel A. (Ed.) The Cytogenetics of Mammalian Autosomal Rearrangements. Alan R. Liss, New York.

Rees H., Shaw D.D., Wilkinson P. 1974. Nuclear DNA variation among acridid grasshoppers. Proceedings Royal Society of London B 202: 517-525.

Remis M.I. 1990. Cytogenetic studies in Sinipta dalmani Stål (Orthoptera: Acrididae). II. Effects of centric fusions on chaisma frequency and distribution. Genétique, Selection, Evolution 22: 263-272.

Rice W.R. 1987. The accumulation of sexually antagonistic genes as a selective agent promoting the evolution of reduced recombination between primitive sex chromosomes. Evolution 41: 911-914.

Rieseberg L H. 2001. Chromosomal rearrangements and speciation. Trends in Ecology and Evolution 17: 351-358.

Roberts H.R. 1941. A comparative study of the sub-families of the Acrididae (Orthoptera) primarily on the basis of their phallic structures. Proceedings Academy of Natural Sciences of Philadelphia 93: 201-246.

Robertson W. 1916. Chromosome studies. I. Taxonomic relationships shown in the chromosomes of Tettigidae and Acrididae. V-shaped chromosomes and their significance in Acrididae, Locustidae and Gryllidae: chromosomes and variation. Journal of Morphology 27: 179-331.

Rowell D.M. 1990. Fixed fusion heterozygosity in Delena cancerides Walck (Araneae: Sparassidae): an alternative to speciation by monobrachial fusion. Genetica 80: 139-157.

Sáez F.A. 1956a. Caso extraordinario de un ortóptero acrídido con ocho cromosomas diploides y mecanismo sexual XY. Biológica 22: 27-30.

Sáez F.A. 1956b. Estudios citogenéticos en ortópteros sudamericanos: el cariotipo de treinta y dos especies. Biológica 22: 21-26.

Sáez F.A. 1957. An extreme karyotype in an orthopteran insect. American Naturalist 91: 259-264.

Sáez F.A., Díaz A. 1960. Neo-X neo-Y system of sex determination in Xyleus laevipes (Orthoptera: Romaleinae). Texas Reports on Biology and Medicine 13: 116-128.
Sáez F.A. 1963. Gradient of heterochromatinization in the evolution of the sexual system "neo-X neo-Y". Portugalia Acta Biologica,. Ser. A, 7: $111-138$.

Sáez F.A., Pérez-Mosquera G. 1970. Citogenética del género Dichroplus (Orthoptera, Acrididae), pp. 111-120. In: Mejía R.H., Moguilevsky J.A. (Eds). Recientes Adelantos en Biología. Bona, Buenos Aires.

Sáez F.A., Pérez-Mosquera G. 1977. Structure, behaviour and evolution of the chromosomes of D. silveiraguidoi (Orthoptera, Acrididae). Genetica 47: 105-114.

Sands V.E. 1988. The meiotic behaviour of neo-XY males in Catantops humilis (Acrididae: Catantopinae). Caryologia 41: 263-274.

Sands V.I. 1990. The neo-XY system of Catantops humilis (Acrididae: Catantopinae) in Malaysia. Biological Journal of the Linnean Society 39: 269-277.

Schwartz J. 2008. In Pursuit of the Gene. From Darwin to DNA. Harvard University Press, Cambridge and London.

Spigler R.B., Lewers K.S., Main D.S., T-L Ashman T.L. 2008. Genetic mapping of sex determination in a wild strawberry, Fragaria virginiana, reveals earliest form of sex chromosome. Heredity 101: 507-517.

Steopoe I. 1939. Nouvelles recherches sur la espermatogénèse chez Gryllotalpa vulgaris de Roumanie. Archives de Zoologie Experimentelle et Généraçe 80: 445-464.

Stevens N.M. 1905. Studies in spermatogenesis with special reference to the "accessory chromosome". Carnegie Institution of Washington 36: 1-33.

Stevens N.M. 1906. Studies in spermatogenesis, Pt. 2: a comparative study of the heterochromosomes in certain species of Coleoptera, Hemiptera, and Lepidoptera, with especial reference to sex determination. Carnegie Institution of Washington 36: 33-75.

Stevens N.M. 1908. A study of the germ cells of certain Diptera, with reference to the heterochromosomes and the phenomena of synapsis. Journal of Experimental Zoology 5: 359-383.

Sutton W.S. 1900. The spermatogonial divisions of Brachystola magna. Kansas University Quarterly 9: 135-160.

Sutton W.S. 1902 On the morphology of the chromosome group in Brachystola magna. Biological Bulletin 4: 24-39.

Sutton W.S. 1903 The chromosomes in heredity. Biological Bulletin 4: 231-251.

Smith S.G., Virkki N. 1978. Animal Cytogenetics 3, Insecta 5. Coleoptera. Gebrüder Borntraeger, Berlin.

Talbert P.B., Bayes J.J., Henikoff S. 2008. Evolution of centromeres and kinetochores: a two-part fugue, pp. 193-230. In: De Wulf P., Earnshaw W.C. (Eds), The Kinetochore: from Molecular Discoveries to Cancer Therapy, Springer, New York.

Turner J.M. 2005. Sex chromosomes make their mark. Chromosoma 114: 300-306

Ueno K., Takai A. 2008. Multiple sex chromosome system of $\mathrm{X}_{1} \mathrm{X}_{1} \mathrm{X}_{2} \mathrm{X}_{2} / \mathrm{X}_{1} \mathrm{X}_{2} \mathrm{Y}$ type in lutjanid fish, Lutjanus quinquelineatus (Perciformes). Genetica 132: 35-41.

Veltsos P., Keller I., Nichols R.A. 2008. The inexorable spread of a newly arisen neo-y chromosome. PloS Genetics 4: e1000082.

Verhulst E.C., van de Zande L., Beukeboom L.W. 2010. Insect sex determination: it all evolves around transformer. Current Opinion in Genetics and Development 20: 370-383.

Viera A., Calvente A., Pradillo M., Rufas J.S., Santos J.L. 2010. Meiosis in Stethophyma (Mecosthetus) grossum (Orthoptera: Acrididae): an exciting story. Journal of Orthoptera Research 19: 267-273.

Warchaowska-Śliwa E., Bugrov A.G., Sugano Y., Maryańska-Nadachowska A., Akimoto S. 2008a. Experimental hybridization between X0 and XY chromosome races in the grasshopper Podisma sapporensis (Orthoptera: Acrididae). II. Cytological analysis of embryos and adults of F1 and F2 generations. European Journal of Entomology 105: 45-52.

Warchalowska-Śliwa E., Tatsuta H., Akimoto S., Maryańska-Nadachowska A., Kowalczyk M., Bugrov A. 2008b. Geographical patterns of chromosomal differentiation in the brachypterous grasshopper Podisma sapporensis (Orthoptera: Acrididae). European Journal of Entomology 105: 185196. 
White M.J.D. 1940a. The origin and evolution of multiple sex-chromosome mechanisms. Journal of Genetics 40: 303-336.

White M.J.D. 1940b. The heteropycnosis of sex chromosomes and its interpretation in terms of spiral structure. Journal of Genetics 40: 67-82.

White M.J.D. 1941a. The evolution of the sex chromosomes. I. The X0 and $\mathrm{X}_{1} \mathrm{X}_{2} \mathrm{Y}$ mechanisms in praying mantids. Journal of Genetics 42: 143-172.

White MJD. 1941b. The evolution of the sex chromosomes. II. The Xchromosome in the Tettigoniidae and Acrididae and the principle of 'evolutionary isolation' of the X. Journal of Genetics 42: 173-190.

White M.J.D. 1945. Animal Cytology and Evolution. MacMillan, New York.

White M.J.D. 1957. Cytogenetics and systematic entomology. Annual Review of Entomology 2: 71-90.

White M.J.D. 1960. Are there no animal species with XO males-and if not, why not? American Naturalist 94: 301-304.

White M.J.D. 1965. Chiasmatic and achiasmatic meiosis in African eumastacid grasshoppers. Chromosoma 16: 271-307.

White M.J.D. 1966. Karyotypes of some members of the grasshopper families Lentulidae and Charilaidae. Caryologia 32:184-189.

White M.J.D. 1968. Karyotypes and nuclear size in the spermatogenesis of grasshoppers belonging to the subfamilies Gomphamastacinae, Chininae and Biroellinae (Orthoptera, Eumastacidae). Caryologia 21: 167-179.

White M.J.D. 1970. Karyotypes and meiotic mechanisms of some Eumastacid grasshoppers from East Africa, Madagascar, India and South America. Chromosoma 30: 61-97.

White M.J.D. 1973. Animal Cytology and Evolution. $3^{\text {rd }}$ Edition Cambridge University Press, Cambridge.

White M.J.D. 1975. Karyotypes in the genus Biroella and the origin of the Australian Morabine grasshoppers. Journal of the Australian Entomological Society 14: 135-138.

White M.J.D. 1976. Animal Cytogenetics, vol.3, Insecta 2. Blattodea, Mantodea, Isoptera, Grylloblattodea, Phasmatodea, Dermaptera and Embioptera. In Animal Cytogenetics. Volume 3. Gebrüder Borntraeger, Berlin. .

White M.J.D. 1978. Modes of Speciation. W.H.Freeman, San Francisco.

White M.J.D.1985. Types of hybrid zones. Italian Journal of Zoology 52: $1-20$.

White M.J.D., Blackith R.E., Blackith R.M., Cheney J. 1967. Cytogenetics of the viatica group of morabine grasshoppers. I. The 'coastal' species. Australian Journal of Zoology 15: 265-302.

White M.J.D., Mesa A. and Mesa R. Neo-XY sex chromosome mechanisms in two species of Tettigonioidea (Orthoptera). Cytologia 32: 190-199.

Wilcox E.V. 1895. Spermatogenesis of Caloptenus femur rubrum and Cicada tibicen. Contributions from Zoological Laboratory Museum of Comparative Zoology at Harvard College 27: 1-32.

Wilson E.B. 1905a. Studies on chromosomes I. The behaviour of the idiochromosomes in Hemiptera. Journal of Experimental Zoology 2: 371-405.

Wilson E.B. 1905b. Studies on chromosomes II. The paired microchromosomes, idiochromosomes and heterotropic chromosomes in Hemiptera. Journal of Experimental Zoology 2: 507-545.

Wilson E.B. 1905c. The chromosomes in relation to the determination of sex in insects. Science 22: 500-502.

Wilson E.B. 1907. Sex determination in relation to fertilization and parthenogenesis. Science 25: 376-379

Wilson E.B. 1909. Recent researches on the determination and heredity of sex. Science 29: 53-70.

Wilson E.B. 1925. The Cell in Development and Heredity. $3^{\text {rd }}$ Edition MacMillan, New York.

Yin T., Di Fazio S.P., Gunter L.E., Zhang X., Sewell M.M., Woolbright S.A., Allan G.J., Kelleher C.T., Douglas C.J., Wang M., Tuskan G.A. 2008. Genome structure and emerging evidence of an incipient sex chromosome in Populus. Genome Research 18: 422-430.

Zhou Q., Wang J., Huang L., Nie W., Wang J., Liu Y., Zhao X., Yang F., Wang W. 2008. Neo-sex chromosomes in the black muntjac recapitulate incipient evolution of mammalian sex chromosomes. Genome Biology 9: R98. 